WSRC-RP--91-975

DE93 003179

\title{
LADTAP XL: AN IMPROVED ELECTRONIC SPREADSHEET VERSION OF LADTAP II
}

D.M. Hamby

Publication Date: November 18, 1991

Westinghouse Savannah River Company Savannah River Site

Aiken, SC 29808 


\section{CONTENTS}

SUMMARY

4

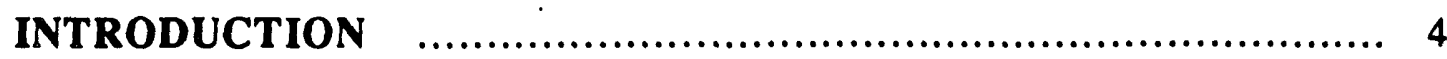

DETERMINATION OF MAXIMUM RIVER CONCENTRATION ...... 5

LIQUID PATHWAY DOSIMETRY MODELS F...................... 6

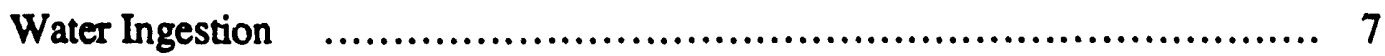

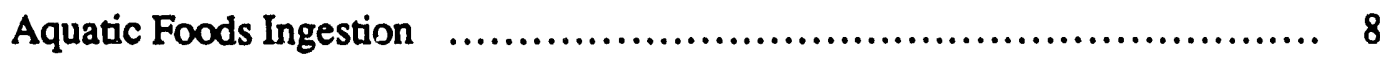

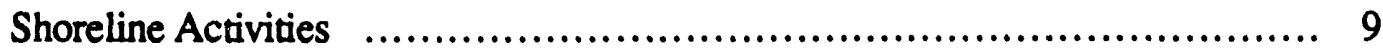

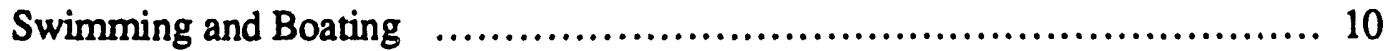

ESTIMATING THE MAXIMUM INDIVIDUAL DOSE $\quad \ldots \ldots \ldots \ldots \ldots \ldots \ldots$

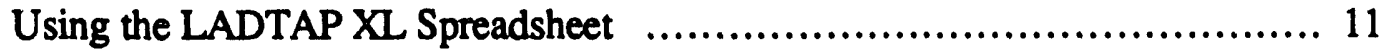

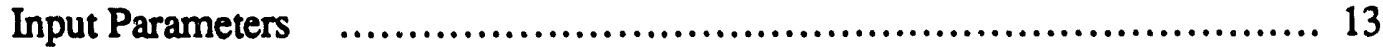

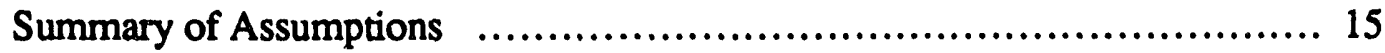

REFERENCES
APPENDIX A
APPENDIX B
APPENDIX C
APPENDIX D 


\title{
LADTAP XL: AN IMPROVED ELECTRONIC SPREADSHEET VERSION OF LADTAP II
}

\author{
D.M. Hamby \\ Westinghouse Savannah River Company \\ Savannah River Site \\ Aiken, SC 29808
}

\section{SUMMARY}

An electronic spreadsheet has been developed to estimate the maximum individual and population dose from chronic liquid releases occurring at the Savannah River Site.

Environmental pathways include external exposure resulting from recreational activities on the Savannah River and ingestion of water, fish, and invertebrates of Savannah River origin. Quality assurance principles are applied by protecting the spreadsheet from unauthorized change and providing version number, time and date on each page of output.

Improvements have been made to LADTAP II's fish and invertebrate consumption pathway model used to estimate population dose. Build-up of shoreline sediments is assumed to have occurred over the past 40 years, the approximate operating time of the Savannah River Site. Additionally, the swimming dose model has been improved by considering tritium absorption through the skin during submersion. Given a typical annual release, the skin absorption dose dominates the swimming and boating dose to both the maximum individual and population.

Comparisons of LADTAP II and LADTAP XI output show that these enhancements result in an insignificant increase in predictions of total dose to the maximum individual and a $10 \%$ increase in total dose to the Savannah River user population.

\section{INTRODUCTION}

The radiological consequences to users of the Savannah River are estimated annually from chronic aqueous discharges to streams on the Savannah River Site (SRS). In the past, the LADTAP II computer program, resident on the unclassified IBM mainframe, has been used for such dose assessments ${ }^{1}$. An EXCEL spreadsheet has been created to predict the 
radiologicai dose to a hypothetical maximum individual and affected populations from chronic liquid releases at the SRS. The "LADTAP XL" spreadsheet, its asstimptions, and its mathematical models are described in this report. A copy of the benchmarking output is given in Appendix A. Verification of each calculation has been carried-out by hand and can be found in Appendix B.

The LADTAP XI transport model estimates river concentrations assuming a continuous and constant release over a period of one year. Nuclide concentrations are determined by simple volumetric dilution without taking into account nuclide depletion except through radioactive decay. Additional dilution in the Savannah River estuary is further accounted for in the use of a dilution factor. Water, fish, and invertebrate consumption can be specified by the user as none, average, or maximum use. River recreational doses are predicted assuming the maximum individual participates in shoreline, swimming, and boating activities for given periods of time during the release year.

The shoreline dose estimates of LADTAP XI assume a long-term, constant buildup of radionuclides in river sediments. Predictions of dose from swimming and boating are determined using identical models. However, as with aquatic ingestion, the usage factors describing the average and maximum individual's habits are user specified. The assumptions incorporated into LADTAP XI have the maximum individual boating and swimming for a user-specified fraction of the year with the dose rate from boating being half the dose rate from swimming.

\section{DETERMINATION OF NUCLIDE CONCENTRATIONS}

As mentioned above, the annual average concentration of nuclide $i$ in the Savannah River, $\mathrm{C}_{\mathrm{i}}^{\mathrm{r}}$, is estimated by volumetric dilution. The river concentration at the receptor location is given by,

$$
\mathrm{C}_{\mathrm{i}}^{\mathrm{r}}=\frac{1.12 \times 10^{-6} \mathrm{~A}_{\mathrm{i}}}{\mathrm{F}_{\mathrm{r}}}
$$

where,

$$
\begin{aligned}
& \mathrm{C}_{\mathrm{i}}^{\mathrm{T}}=\text { river concentration of nuclide } \mathrm{i},\left[\mu \mathrm{Ci} \mathrm{m}^{-1}\right] \text {; } \\
& 1.12 \times 10^{-6}=\text { conversion factor, }\left[\mu \mathrm{Ci} \mathrm{ft}^{3} \mathrm{yr} \mathrm{Ci}^{-1} \mathrm{ml}^{-1} \mathrm{sec}^{-1}\right] \text {; } \\
& \left.A_{i}=\text { activity of nuclide } i \text { released, [Ci yr }{ }^{-1}\right] \text {; and }
\end{aligned}
$$




$$
F_{\mathrm{r}}=\text { assumed river flow rate at one of four locations, }\left[\mathrm{ft}^{3} \mathrm{sec}^{-1}\right] \text {. }
$$

Since the released radioactivity is being dispersed as it travels down the river, the simple dilution model results in a conservative concentration estimate. When assessing dose in a retrospective study, river flow rates are measured at Highway 301 and the estuary; flow rates at Beaufort-Jasper and Port Wentworth are estimated based on measured concentrations of tritium in the domestic water supplies. For prospective dose assessments historical flow rates are utilized to determine daily and annual average flows. Appendix $C$ contains a copy of the summary to "Historical River Flow Rates for Dose Calculations". 2 Recommended flow rates for prospective studies are given in Table 1.

\section{Table 1. Assumed Savannah River Flow Rates for Prospective Dose Assessments.}

$\begin{array}{ccc} & \text { Elow Rate (cfs) at Specified Location } \\ \text { Assessment (flow avg.) } & \text { Hwy } 301 & \begin{array}{c}\text { Beaufort-Jasper and } \\ \text { Port Wentworth }\end{array}\end{array}$

$\begin{array}{lcc}\text { Routine (annual avg.) } & 10,500 & 13,000 \\ \text { Minimal Flow (annual avg.) } & 5,300 & 6,600 \\ \text { Accident (daily avg.) } & 3,900 & 4,900\end{array}$

Equation 1 does not include radioactive decay since transit times differ when estimating maximum individual and population dose. Radioactive decay occurring between release and exposure is accounted for in the individual pathway models that follow. Concentrations appearing in the spreadsheet are those calculated before decay has been considered.

\section{LIQUID PATHWAY DOSIMETRY MODELS}

The pathways considered in LADTAP XL include ingestion of river water, ingestion of fish and invertebrates of Savannah River origin; and swimming, boating, and recreational shoreline activities. The maximum individual is assumed to reside on the Savannah River at a downstream location where complete mixing occurs. This individual consumes untreated water and fish taken from the river; invertebrate consumption is only considered 
in the estimation of population dose. The maximum individual is also assumed to swim in and boat on the Savannah River during the course of the release year. Exposure to shoreline sediments also occurs during the year.

Dose to the population is calculated by summing average doses to the following receptors: (1) drinking water users at Beaufort-Jasper and Port Wentworth, (2) recreational users of the Savannah River, (3) consumers of fish from the Savannah River, and (4) consumers of invertebrates from the Savannah River estuary. The pathway models used in LADTAP XI are given below and are similar to those described in Regulatory Guide 1.109.3

\section{Water Ingestion}

The nuclide-specific dose to an individual from the ingestion of river water is given by,

$$
D_{i}^{W}=U_{W} t^{I} C_{i}^{C} D F_{i} e^{-\lambda_{i}} \omega
$$

where,

$$
\begin{aligned}
& D_{i}^{W}=\text { individual drinking water dose from nuclide } \mathrm{i}, \text { [mrem]; } \\
& \mathrm{U}_{\mathrm{W}}=\text { water consumption rate, }\left[\mathrm{L} \mathrm{yr}^{-1}\right] \text {; } \\
& \mathrm{t}^{\mathrm{I}}=\text { intake duration, [yr]; } \\
& \mathrm{C}_{\mathbf{i}}^{r}=\text { concentration of nuclide } \mathrm{i} \text { in river water, }\left[\mu \mathrm{Ci} \mathrm{L}^{-1}\right] \text {; } \\
& \mathrm{DF}_{\mathrm{i}}=\text { ingestion dose factor for nuclide } \mathrm{i},\left[\mathrm{mrem} \mu \mathrm{Ci}^{-1}\right] \text {; } \\
& \lambda_{i}=\text { radioactive decay constant for nuclide } i,\left[d^{-1}\right] ; \text { and } \\
& t_{w}=\text { transit time between release and consumption, [d]. }
\end{aligned}
$$

The NRC Regulatory Guide $1.109^{3}$ or the current SRS usage survey ${ }^{4}$ should be consulted for appropriate usage and consumption rates. Drinking water population doses are estimated for Beaufort-Jasper (BJ) and Port Wentworth (PW) consumers by multiplying the consumer population times the average individual drinking water dose determined using $\mathrm{BJ}$ and $\mathrm{PW}$ water concentrations and Equation 2. Water ingestion pathway dose models in LADTAP II and LADTAP XI are identical. 


\section{Aquatic Foods Ingestion}

The nuclide-specific dose to an individual from the consumption of contaminated aquatic foods is estimated by,

$$
D_{i}^{F}=U_{F} t^{I} \quad C_{i}^{r} D F_{i} B_{i} e^{-\lambda_{i} u}
$$

where,

$$
\begin{aligned}
D_{i}^{F} & =\text { individual dose from consumption of aquatic foods, [mrem]; } \\
U_{F} & =\text { aquatic foods consumption rate, }[\mathrm{kg} / \mathrm{yr}] ; \\
\mathfrak{t}^{I} & =\text { intake duration, [yr]; } \\
C_{\mathrm{i}}^{r} & =\text { maximum nuclide concentration in river water, }\left[\mu \mathrm{Ci} \mathrm{L} \mathrm{L}^{-1}\right] ; \\
D_{\mathrm{i}} & =\text { ingestion dose factor, }\left[\mathrm{mrem} \mu \mathrm{Ci}^{-1}\right] ; \\
B_{i} & =\text { bioaccumulation factor, }\left[\mathrm{L} \mathrm{kg}^{-1}\right] \\
\lambda_{i} & =\text { radioactive decay constant, }\left[\mathrm{d}^{-1}\right] ; \text { and } \\
t_{f} & =\text { transport time between harvest and consumption, }[\mathrm{d}] .
\end{aligned}
$$

Equation 5 is used to calculate dose from both fish and invertebrate consumption. Fish and invertebrates are assumed to be in equilibrium with nuclide concentrations in the Savannah River. Except for a site-specific factor of $3000 \mathrm{~L} / \mathrm{kg}$ for cesium accumulation in freshwater fish, bioaccumulation factors for freshwater fish and saltwater invertebrates were obtained from reference 1. Maximum individual dose estimates generated by LADTAP XI are the same as those calculated using LADTAP II.

The assumption is made in LADTAP II that commercial fish and saltwater invertebrates harvested from the Savannah River are consumed by the entire U.S. population, effectively reducing the 50-mile population dose. More conservatively, the 50-mile population dose is determined in LADTAP XL assuming that the total harvest is consumed by the population. The consumption rate and intake duration in equation 5 are replaced by the annual amount of aquatic foods harvested (in $\mathrm{kg}$ ). If, in the case of a small population or large annual harvest, some of the harvested seafood is exported from the 50-mile region, only the aquatic foods needed to support the population are assumed to be consumed.

In Appendix D a comparison is shown between LADTAP II and LADTAP XL dose estimates by nuclide resulting from the consumption of commercial fish and invertebrates. 
Dose predictions using LADTAP XL are larger because the total commercial harvest is assumed to be ingested by the 50-mile population.

\section{Shoreline Activities}

The LADTAP XI spreadsheet uses a model developed by Soldat, et al. ${ }^{5}$ to obtain an estimate of the sediment concentration resulting from the deposition of waterborne radionuclides. The model was developed using data collected over several years and is said to produce an "order of magnitude estimate". The model does not consider removal of surface contamination by weathering. The "effective" surface contamination, $\mathrm{S}_{\mathrm{i}}$, in units of activity per unit area, is estimated by,

$$
D_{i}^{S H}=100 U_{S H} 0.2 C_{i} \tau_{i} D_{i}^{G}\left\{1-e^{-\lambda_{i l b}}\right\}
$$

where,

$$
\begin{aligned}
\mathrm{D}_{\mathrm{i}}^{\mathrm{SH}} & =\text { individual dose from exposure to shoreline sediments, [mrem]; } \\
100 & =\text { water-to-sediment transfer coefficient, }\left[\mathrm{L} \mathrm{m}^{-2}\right. \text { day-1]; } \\
\mathrm{U}_{\mathrm{SH}} & =\text { time exposed to shoreline annually, [yr]; } \\
0.2 & =\text { shore width factor, [unitless]; } \\
\mathrm{C}_{\mathrm{i}}^{r} & =\text { concentration of nuclide } \mathrm{i} \text { in river water, }\left[\mu \mathrm{Ci} \mathrm{L}^{-1}\right] \\
\tau_{\mathrm{i}} & =\text { radiological half-life of nuclide } \mathrm{i},[\text { day]; } \\
\mathrm{DF}_{\mathrm{i}}^{\mathrm{G}} & \left.=\text { ground-shine dose factor, [mrem } \mathrm{m}^{2} \mathrm{yr}^{-1} \mu \mathrm{Ci}^{-1}\right] \\
\lambda_{\mathrm{i}} & =\text { radioactive decay constant of nuclide } \mathrm{i},[\mathrm{yrs}] ; \text { and } \\
t_{\mathrm{b}} & =\text { time sediment is exposed to contaminated water, [40 yrs]. }
\end{aligned}
$$

It is assumed that the buildup (and decay) of nuclides, based on the current release, in Savannah River shoreline sediments has occurred for the past 40 years, the approximate operating period thus far of SRS facilities. The LADTAP II assumption of a 15 year buildup results in a lower dose from shoreline exposure for the longer-lived nuclides. Appendix D also contains a comparison of shoreline dose, assuming unit curie releases of each nuclide, using 40 and 15 year buildup times. Population dose estimates are determined by substituting individual shoreline exposure times with estimated population exposures times (in units of person-hrs). 


\section{Swimming and Boating}

The maximum individual is assumed to participate in boating and swimming activities for a given period during the release year. The external dose received from swimming or boating is estimated for each nuclide by,

$$
D_{i}^{S}=G t_{s} C_{i} D F_{i}
$$

where,

$$
\begin{aligned}
D_{i}^{S} & =\text { individual dose from exposure while swimming, [mrem]; } \\
G & =\text { geometry factor (1 for swimming, } 0.5 \text { for boating); } \\
t_{s} & =\text { time spent swimming or boating, }[\mathrm{yr}] ; \\
C_{i}^{+} & =\text {concentration of nuclide } \mathrm{i} \text { in river water, }[\mu \mathrm{Ci} \mathrm{m}-3 \text { ]; and } \\
D F_{i} & =\text { water submersion dose factor for nuclide } \mathrm{i}\left[\mathrm{mrem} \mathrm{m}^{3} \mathrm{yr}^{-1} \mu \mathrm{Ci}^{-1}\right]
\end{aligned}
$$

Complete submersion is assumed while swimming (geometry factor $=1$ ). While boating, the maximum individual is assumed to be on the surface of the contaminated water (geometry factor $=0.5$ ). Minimal shielding, provided by the boat's hull, is not considered. Population doses are determined in a manner similar to that for shoreline exposure.

Tritium dose obtained via skin absorption while swimming has been considered in LADTAP XL since tritium concentrations in the Savannah River from chronic releases are potentially high enough for a significant skin absorption dose (relative to external swimming and boating doses). Tritium dose from skin absorption, $\mathrm{D}_{\mathrm{T}}^{\text {Skin }}$, is estimated in LADTAP XL using Equation 10.

$$
D_{T}^{S k i n}=t_{s} C_{T}^{r} D_{T} I_{T}^{\text {skin }}
$$

where,

$$
\begin{aligned}
t_{s} & =\text { time spent swimming, }[\mathrm{hr}] \\
\mathrm{C}_{\mathrm{T}}^{\mathrm{r}} & =\text { concentration of tritium in river water }[\mu \mathrm{Ci} / \mathrm{ml}] \\
\mathrm{DF}_{\mathrm{T}} & =\text { ingestion dose factor for tritium }[\mathrm{rem} / \mu \mathrm{Ci}] \text {, and } \\
\mathrm{I}_{\mathrm{T}}^{\text {skin }} & =\text { water absorption rate for total body submersion }[35 \mathrm{ml} / \mathrm{hr}]
\end{aligned}
$$


Tritium absorption through the skin has been studied for both air and water immersion. 6,7 Pinson and Langham ${ }^{7}$ have studied the rate of water absorption through the skin while exposed to HTO in the vapor and liquid phases. Their data are used to determine water absorption via submersion assuming an average body area of $1.9 \mathrm{~m}^{2} .6$ Total water absorption as a function of submersion time is plotted in Figure 1.

A linear regression of the data shows that the absorption rate of water through the skin, in the vapor phase, is approximately $14 \mathrm{ml} / \mathrm{hr}$ in an atmosphere of $100 \%$ relative humidity and a temperature of $24^{\circ} \mathrm{C} .^{7}$ Absorption through the skin while submersed in liquid water at the same temperature occurs at a rate two-and-one-half times faster, $35 \mathrm{ml} / \mathrm{hr}$. This absorption rate is used in LADTAP XI to estimate the maximum individual's dose from absorption of tritium through the skin while swimming in the Savannah River.

\section{ESTIMATING THE MAXIMUM INDIVIDUAL DOSE}

\section{Using the LADTAP XL Spreadsheet}

LADTAP XL is an EXCEL spreadsheet (Version 2.2) developed on a Macintosh II. An IBM version is also available. A total of 37 nuclides can be included in the dose calculation. All nuclides known to have been released to aqueous streams from the SRS in forty years of operations are included in the list of available nuclides.

River flow rates at various downstream locations, pathway transport times, and all consumption and usage factors appear on the first page of the spreadsheet. The user is able to change only those values shown in red (on the monitor). The input parameters are checked at two validity levels. If an input value is outside the range of the first validity level the expected value and an asterisk appear to the right of the value indicating that the value is unexpected yet acceptable. If the input value is outside the second validity range the word "INVALID" appears in place of the asterisk indicating that the calculations of dose are highly questionable. In the second case the input value causing the INVALID statement should be replaced with an acceptable value. The water, fish, and invertebrate usage, or consumption, queries are answered with either "Avg", "Max", or "None" to indicate which preset consumption rates are to be used in the dose predictions. A response that is not recognized is treated as "None". 
The source term appears on the second page. Values of released activity, in curies per year, again, appear in red and are entered in the second column. The source term is checked for negative values and for values that are greater than the total activity released for a given nuclide in SRS history. The word "INVALID" appears to the right of the released activity value if it is negative; an asterisk appears for an unusually high value.

Average river concentrations at four downstream locations are calculated using the source term and the river flow rates entered by the user. The river concentrations are calculated as shown in Equation 1. These concentrations, which, as mentioned earlier, do not account for radioactive decay during transit, appear on page two. For purposes of quality assurance, only cells appearing on the spreadsheet in red can be changed by the user. The LADTAP XI version number along with the current time and date appear at the bottom of each printed page.

The third page contains decay constants; ingestion, ground-shine, and water immersion dose factors; and bioaccumulation factors for ireshwater fish and saltwater invertebrates. The dose factors are taken directly from DOE/EH-0070 and DOE/EH-0071 (see references 8 and 9) with some modifications allowing for daughter ingrowth (see reference 10).

Page four shows estimates of fish ingestion, water ingestion, swimming and boating, and shoreline dose to the maximum individual by nuclide. A summary of the maximum individual dose is given at the top of the page.

Drinking water doses, both maximum individual and population, are given by nuclide on the fifth page. Dose estimates for users of domestic water from the Beaufort-Jasper and Port Wentworth water treatment facilities are determined using a maximum individual consumption rate $(730 \mathrm{~L} / \mathrm{yr})$ and a population consumption rate $(370 \mathrm{~L} / \mathrm{yr}$ multiplied by the user population). A summary of individual and population dose is given at the top of the page. The total population dose via drinking water is the sum of the population doses from each of the two domestic water systems.

The last page provides dose estimates for the 50-mile population, centered on the SRS. This population is assumed to eat fish and invertebrates of Savannah River origin and participate in recreational activities on the river. Total fish and invertebrate consumption is calculated on the first page of LADTAP XL. This total is the average or maximum consumption rate (whichever is chosen by the user) multiplied by the 50 -mile population. 
If the harvest exceeds the total consumption, food is exported out of the dose assessment region. In this case, the word "EXPORT" appears on the first page to the right of the total fish and invertebrate consumption values. If, however, total consumption exceeds the harvest, imported seafood is consumed. Population dose, by nuclide, is shown on page six with dose summed over all nuclides appearing at the top of the page.

A benchmark execution of LADTAP XL is given in Appendix A. The benchmarking scenario assumes one curie of each nuclide is present in the effluent. The maximum individual consumes average amounts of river water and maximum amounts of fish. The 50-mile population is assumed to consume average amounts of fish and invertebrates harvested from the Savannah River. River flow rates in the example are as follows: (1) Hwy $301-10,426$ cfs; (2) BJ - 15,775 cfs; (3) PW - 12,958 cfs; and (4) Estuary - 13,270 cfs. All other parameter values are as specified in reference 3. Occasional execution of the benchmark scenario will ensure proper operation of LADTAP XI.

\section{Input Parameters}

The LADTAP XI spreadsheet is desig,led to give the user flexibility in setting input parameters to assess impacts of chronic releases under various conditions. Acceptable input ranges, however, have been placed on all of the input parameters to ensure valid interpretation of the results. Spreadsheet values appearing in RED (on the monitor) are those which are changeable by the user. Each value, once entered, is checked for validity. If an entered value is outside its pre-assigned range, a message will appear on the spreadsheet as discussed above. A description of each input parameter and its acceptable range is given below.

River Flow Rates [cfs]: The average annual Savannah River flow rate. Four values are requested: (1) measured flow at Highway 301, (2) "effective" flow at Beaufort-Jasper, (3) "effective" flow at Port Wentworth, and (4) estimated flow at the Savannah River estuary. Flow rates for prospective dose assessments are determined according to guidance provided in Reference 2. Estuary flow rates are estimated by increasing the measured flow at Highway 301 by $10 \%$. The range is bounded by the lowest and highest recorded daily river flow rates at Hwy 301 since the construction of Thurmond Dam.

Expected Range: $5,300-25,000 \mathrm{cfs}$.

Valid Range: $3,900-77,000 \mathrm{cfs}$. 
Recreation Usage [hr]: Number of hours per year spent in a recreational activity on the Savannah River.

Shoreline Expected Value: $23.0 \mathrm{hrs}$.

Swimming Expected Value: $8.9 \mathrm{hrs}$.

Boating Expected Value: $21.0 \mathrm{hrs}$.

Valid Range: 0 - 8,760 hrs.

MI Fish and Water Usage: Fish and water consumption rates for the maximum individual dose estimation. This individual resides on the Savannah River at a point where complete mixing occurs. Fish Consumption Rates: $9 \mathrm{~kg} / \mathrm{yr}$ avg.; $19 \mathrm{~kg} / \mathrm{yr} \max$. Water Consumption Rates: $370 \mathrm{~L} / \mathrm{yr}$ avg.; $730 \mathrm{~L} / \mathrm{yr}$ max. Valid Response: "Avg", "Max", or "None".

Transport Time [days]: Times used for radioactive decay between release and exposure or consumption. Times used for the maximum individual calculation. This value is only used to decrease the concentration of nuclides through radioactive decay. Recreation Expected Value: 1.0 day. Water Expected Value: 1.5 days.

Fish/Invert Expected Value: 2.0 days. Valid Range: 0 - 10 days.

Populations [persons]: Drinking water consumers on the Beaufort-Jasper and Port Wentworth domestic water systems and the population within 50-miles of the SRS geographic center. Beaufort-Jasper Expected Value: 50,000 persons Port Wentworth Expected Value: 15,000 persons 50-Mile Expected Value: 555,100 persons

Valid Range: 0 - 1,000,000 persons

BJ/PW Travel Time [days]: Time used for radioactive decay before consumption; includes transit down the Savannah River, water treatment, and system residence.

Expected Value: 4.0 days.

Valid Range: 0 - 10 days.

Population Usage $[\mathrm{kg} / \mathrm{yr}]$ : Water, fish, and invertebrate consumption rates used in calculating dose to the Beaufor-Japser and Port

Wentworth water users and the 50-mile population. Water Consumption Rates: same as individual usage. Fish Consumption Rates: same as individual usage. Invertebrate Consumption: $2 \mathrm{~kg} / \mathrm{yr}$ avg.; $8 \mathrm{~kg} / \mathrm{yr} \max$. Valid Response: "Avg", "Max", or "None".

Total 50-Mile Consumption: Values calculated by LADTAP XL indicating the maximum amounts of fish and invertebrates consumed by the 50-mile population. The values are determined by multiplying the 50 -mile population by the consumption rates chosen above. 
Aquatic Harvests [kg/yr]: Total amounts of edible fish and seafood harvested from the Savannah River in an average year.

Sport Fish Expected Value: $35,000 \mathrm{~kg} / \mathrm{yr}$.

Commercial Fish Expected Value: 2,700 kg/yr.

Invertebrate Expected Value: $390,000 \mathrm{~kg} / \mathrm{yr}$.

Valid Range: 0 - 1,000,000 kg/yr.

Travel Times [days]: Time used for radioactive decay before consumption of sport fish and commercial fish/invertebrates. These values are used when calculating dose to the 50-mile population.

Sport Fish Expected Value: 10 days.

Commercial/Invertebrate Expected Value: 13 days.

Valid Range: 0 - 30 days.

Estuary Dilution Factor: Unitless factor accounting for increased dilution in the

Savannah River estuary. Nuclide concentrations in the estuary are calculated using volumetric dilution (determine by the average annual flow rate) and the dilution factor. The estuary concentrations are used to estimate concentrations of nuclides in the saltwater invertebrates consumed by the 50 -mile population.

Expected Value: 3

Valid Range: 1 - 10

Recreation Usage (per-hrs): Recreational usage of the Savannah River and its shoreline in units of total person-hours per year. These values are used to calculate dose to the 50-mile population.

Shoreline Expected Value: 960,000 person-hrs.

Swimming Expected Value: 160,000 person-hrs.

Boating Expected Value: 1,100,000 person-hrs.

Valid Range: 0 - 1,500,000 person-hrs.

Released Activity [Ci/yr]: Total activity of specified nuclide reaching the Savannah

River over the course of one year. This activity is assumed to be released at a constant and continuous rate. The valid range is any non-negative number that is no larger than the maximum amount released from the SRS between 1954 and 1988.

Valid Range: 0 - MAX (varies among nuclides).

\section{Summary of Assumptions}

The following is a composite list of assumptions used in the LADTAP XI spreadsheet calculations of maximum individual and population dose from normal operating aqueous releases.

- River concentrations determined by volumetric dilution.

- Nuclide depletion only through radioactive decay. 
- Aquatic life is in equilibrium with river concentrations.

- Sport and commercial fish are harvested in freshwater while invertebrates are harvested in saltwater.

- Shoreline width factor is 0.2 (see reference 4).

-Water-to-sediment transfer coefficient equals $100\left[\mathrm{~L} \mathrm{~m}^{-2}\right.$ day-1] (see reference 4).

- Swimming dose is calculated assuming complete submersion.

- Skin aborption rate of tritium during submersion is $35 \mathrm{~m} / \mathrm{hr}$ (reference 7).

- Boating dose is one-half of swimming dose assuming half immersion and no shielding. 


\section{REFERENCES}

1. Radiation Shielding and Information Center, "LADTAPII: A Program for Calculating Radiation Exposure to Man from Routine Release of Nuclear Reactor Liquid Effluents", CCC-363, Oak Ridge National Laboratory, March 1980.

2. Hayes, D.W. and Marter, W.L., "Historical River Flow Rates for Dose Calculations", SRL-ETS-910257, Westinghouse Savannah River Laboratory, Aiken, SC, June 1991.

3. U.S. Nuclear Regulatory Commission, "Regulatory Guide 1.109: Calculation of Annual Dose to Man from Routine Releases of Reactor Effluents for the Purpose of Evaluating Compliance with 10 CFR Part 50, Appendix I", Revision 1, October 1977.

4. Hamby, D.M., "Land and Water Use Characteristics in the Vicinity of the Savannah River Site", WSRC-RP-91-17, Westinghouse Savannah River Company, Savannah River Laboratory, Aiken, SC, 1991.

5. Soldat, J.K., Robinson, N.M, and Baker, D.A., "Models and Computer Codes for Evaluating Environmental Radiation Doses", BNWL-1754, Pacific Northwest Laboratory, Richland, Washington, 1974.

6. Osborne, R.V., "Absorption of Tritiated Water Vapour by People", Health Physics, 12:1527, 1966.

7. Pinson, E.A., and Langham, W.H., "Physiology and Toxicology of Tritium in Man", J. Appl. Physiol., 10:108, 1957.

8. US Department of Energy, "External Dose Conversion Factors for Calculation of Dose to the Public", DOE/EH-0071, Washington, DC, July, 1988.

9. US Department of Energy, "Internal Dose Conversion Factors for Calculation of Dose to the Public", DOE/EH-0071, Washington, DC, July, 1988. 
10. Hamby, D.M., "Adjustments to DOE's External Dose Factors for Estimates of Dose from Routine Releases", SRL-ETS-910233, Rev. 1, Westinghouse Savannah River Company, Savannah River Laboratory, Aiken, SC, May 1991. 


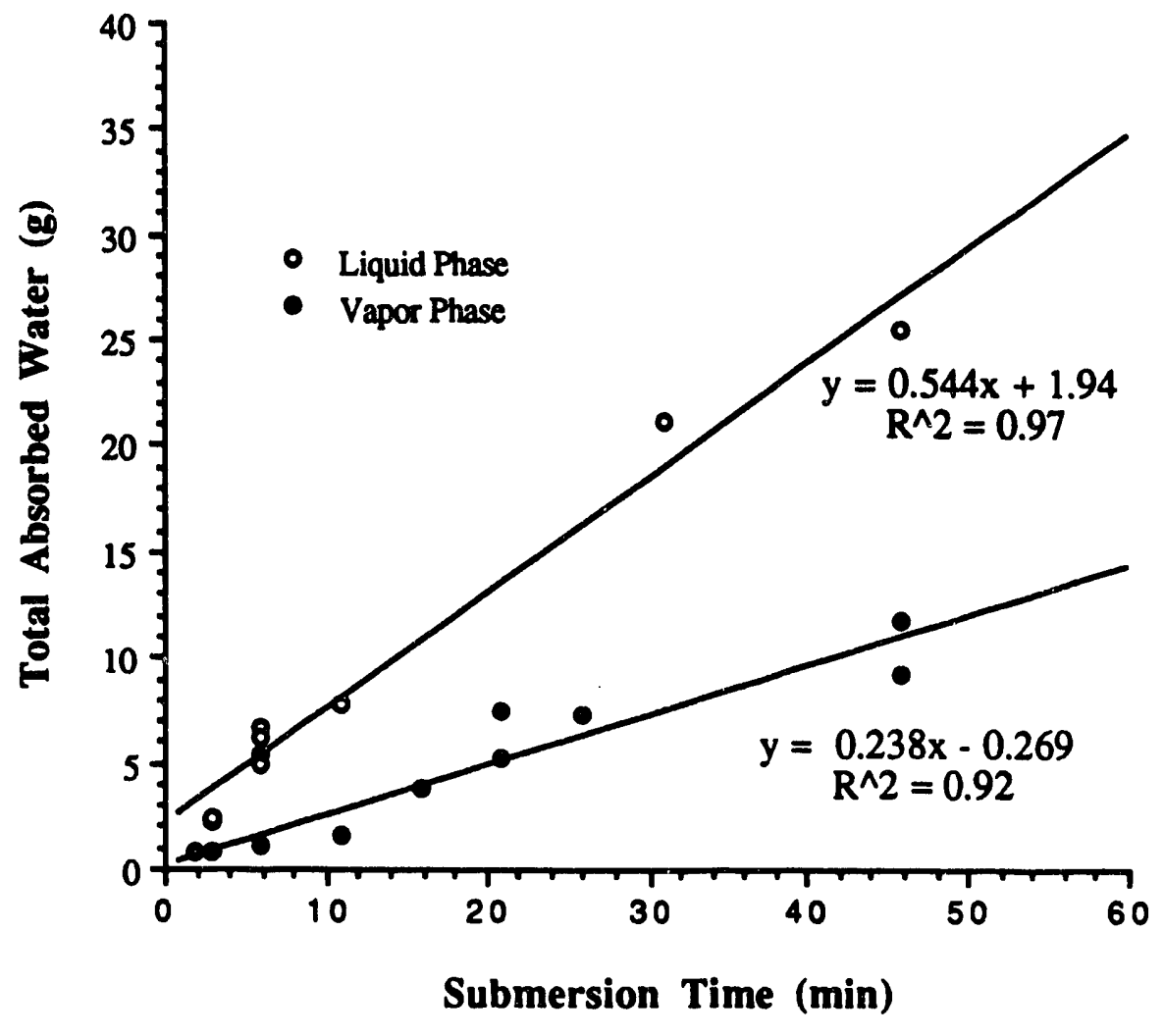

Figure 1. Water absorbed through the skin while exposed to HTO in the vapor and liquid phases as a function of time. Calculated from data of

Pinson and Langham (ref. 7). 
APPENDIX A

LADTAP XL Benchmark 
INSTRUCTIONS:

1.) LADTAP $X L$ is to be used for chronic aqueous release scenarios.

2.) Enter the flow and exposure parameters. Only the numbers in RED are changeable. A description of each is given in the user's documentation.

3.) Enter the source term (curies per year released to the Savannah River).

\section{Benchmarking Run}

\section{FLOW \& EXPOSURE PARAMETERS}

Measured River Flow Rate (Hwy 301):

Flow Rate at Beaufort-Jasper:

Flow Rate at Port Wentworth:

Flow Rate at the Estuary:

Annual Max. Ind. Shoreline Usage:

Annual Max. Ind. Swimming Usage:

Annual Max. Ind. Boating Usage:

Max. Ind. Fish Usage (Avg, Max, None):

Max. Ind. Water Usage (Avg, Max, None):

Recreation Transport Time:

Water Transport Time:

Fish/Invertebrate Transport Time:

Beaufort-Jasper Population:

Port Wentworth Population:

50-Mile Population:

BJ/PW Travel Time:

Pop. Water Usage (Avg, Max, None):

Pop. Fish Usage (Avg, Max, None):

Pop. Invertebrate Usage (Avg, Max, None):

Total 50-Mile Fish Consumption:

Total 50-Mile Invertebrate Consumption:

Annual Sport Fish Harvest (edible):

Annual Commercial Fish Harvest (edible):

Annual Invertebrate Harvest (edible):

Sport Fish Transport Time:

Commercial/Invertebrate Transport Time:

Estuary Dilution Factor:

Population Shoreline Usage:

Population Swimming Usage:

Population Boating Usage:

\begin{tabular}{|c|c|}
\hline $\begin{array}{c}10,426 \\
15,775 \\
12,958 \\
13,270 \\
23.0 \\
8.9 \\
21.0\end{array}$ & $\begin{array}{l}\text { (cfs) } \\
\text { (cfs) } \\
\text { (cfs) } \\
\text { (cfs) } \\
\text { (hr) } \\
\text { (hr) } \\
\text { (hr) }\end{array}$ \\
\hline $\max$ & $19(\mathrm{~kg} / \mathrm{yr})$ \\
\hline Avg & 370 (L/yr) \\
\hline 1.0 & (d) \\
\hline 1.5 & (d) \\
\hline 2.0 & (d) \\
\hline 50000 & (persons) \\
\hline 15000 & (persons) \\
\hline 555100 & (persons) \\
\hline 4.0 & (d) \\
\hline Avg & $370(\mathrm{~L} / \mathrm{yr})$ \\
\hline Avg & $9(\mathrm{~kg} / \mathrm{yr})$ \\
\hline Avg & $2(\mathrm{~kg} / \mathrm{yr})$ \\
\hline $5.0 E+06$ & (kg/yr) \\
\hline $1.1 E+06$ & (kg/yr) \\
\hline $3.5 E+04$ & $(\mathrm{~kg} / \mathrm{yr})$ \\
\hline $2.7 E+03$ & $(\mathrm{~kg} / \mathrm{yr})$ \\
\hline $3.9 E+05$ & (kg/yr) \\
\hline 10.0 & (d) \\
\hline 13.0 & (d) \\
\hline 3 & (unitless) \\
\hline $9.6 E+05$ & (person-hrs) \\
\hline $1.6 E+05$ & (person-hirs) \\
\hline $1.1 E+06$ & (person-hrs) \\
\hline
\end{tabular}




\section{SOURCE TERM AND RIVER CONCENTRATIONS}

\begin{tabular}{|c|c|c|c|c|c|}
\hline \multirow[b]{2}{*}{ Nuclide } & \multirow[b]{2}{*}{$\begin{array}{l}\text { Released } \\
\text { Activity } \\
\text { (Ci/yr) }\end{array}$} & \multicolumn{4}{|c|}{ AVERAGE UNDECAYED CONCENTRATLONS (uCi/mU) } \\
\hline & & $\begin{array}{c}\text { Hwy } 301 \text { Flow } \\
\text { Rate (cfs) } \\
10,426 \\
\end{array}$ & $\begin{array}{c}\text { BJ Flow } \\
\text { Rate (cfs) } \\
15,775\end{array}$ & $\begin{array}{c}\text { PW Flow } \\
\text { Rate (cfs) } \\
12,958 \\
\end{array}$ & $\begin{array}{c}\text { Estuary Flow } \\
\text { Rate (cfs) } \\
13,270 \\
\end{array}$ \\
\hline $\mathrm{H} \cdot \mathbf{3}$ & $1.00 E+00$ & $1.07 E-10$ & $7.10 \mathrm{E}-11$ & $8.64 E-11$ & $2.81 E-11$ \\
\hline P.32 & $1.00 E+00$ & $1.07 E-10$ & $7.10 E-11$ & $8.64 E-11$ & $2.81 E-11$ \\
\hline S-35 & $1.00 E+00$ & $1.07 E-10$ & $7.10 E-11$ & $8.64 E-11$ & $2.81 E-11$ \\
\hline Cr-51 & $1.00 E+00$ & $1.07 E-10$ & $7.10 E-11$ & $8.64 E-11$ & $2.81 E-11$ \\
\hline$M n-54$ & $1.00 E+00$ & $1.07 E-10$ & $7.10 E-11$ & $8.64 E-11$ & $2.81 E-11$ \\
\hline Co-58 & $1.00 E+00$ & $1.07 E-10$ & 7.10 E-11 & $8.64 E-11$ & $2.81 E-11$ \\
\hline Co-60 & $1.00 E+00$ & $1.07 E-10$ & 7.10 E-11 & $8.64 E-11$ & $2.81 E-11$ \\
\hline $\mathrm{Zn}-65$ & $1.00 E+00$ & $1.07 E-10$ & $7.10 \mathrm{E}-11$ & $8.64 E-11$ & $2.81 E-11$ \\
\hline Sr-89 & $1.00 E+00$ & 1.07E-10 & $7.10 E-11$ & $8.64 E-11$ & $2.81 E-11$ \\
\hline Sr-90 & $1.00 E+00$ & $1.07 E-10$ & $7.10 \mathrm{E}-11$ & $8.64 E-11$ & $2.81 E-11$ \\
\hline$Y-91$ & $1.00 E+00$ & $1.07 E-10$ & $7.10 \mathrm{E}-11$ & $8.64 E-11$ & $2.81 E-11$ \\
\hline $\mathrm{Zr-95 \dagger}$ & $1.00 E+00$ & $1.07 E-10$ & $7.10 E-11$ & $8.64 E-11$ & $2.81 E-11$ \\
\hline Nb-95 & $1.00 E+00$ & $1.07 E-10$ & $7.10 \mathrm{E}-11$ & $8.64 E-11$ & $2.81 E-11$ \\
\hline Mo-99 & $1.00 E+00$ & $1.07 E-10$ & $7.10 \mathrm{E}-11$ & $8.64 E-11$ & $2.81 E-11$ \\
\hline$R u-103$ & $1.00 E+00$ & 1.07E-10 & $7.10 \mathrm{E}-11$ & $8.64 E-11$ & $2.81 E-11$ \\
\hline$R u-106 t$ & $1.00 E+00$ & $1.07 E-10$ & $7.10 \mathrm{E}-11$ & $8.64 E-11$ & $2.81 E-11$ \\
\hline Sb-124 & $1.00 E+00$ & $1.07 E-10$ & $7.10 \mathrm{E}-11$ & $8.64 E-11$ & $2.81 E-11$ \\
\hline Sb-125 & $1.00 E+00$ & $1.07 E-10$ & $7.10 E-11$ & $8.64 E-11$ & $2.81 E-11$ \\
\hline $1-129$ & $1.00 E+00$ & $1.07 E-10$ & $7.10 E-11$ & $8.64 E-11$ & $2.81 E-11$ \\
\hline $1-131$ & $1.00 E+00$ & $1.07 E-10$ & $7.10 \mathrm{E}-11$ & $8.64 E-11$ & $2.81 E-11$ \\
\hline Cs-134 & $1.00 E+00$ & $1.07 E-10$ & $7.10 \mathrm{E}-11$ & $8.64 E-11$ & $2.81 E-11$ \\
\hline Cs-137 & $1.00 E+00$ & $1.07 E-10$ & $7.10 E-11$ & $8.64 E-11$ & $2.81 E-11$ \\
\hline $\mathrm{Ba}-140$ & $1.00 E+00$ & $1.07 E-10$ & $7.10 E-11$ & $8.64 E-11$ & $2.81 E-11$ \\
\hline La-140 & $1.00 E+00$ & $1.07 E-10$ & $7.10 \mathrm{E}-11$ & $8.64 E-11$ & $2.81 E-11$ \\
\hline $\mathrm{Ce}-141$ & $1.00 E+00$ & $1.07 E-10$ & $7.10 \mathrm{E}-11$ & $8.64 E-11$ & $2.81 E-11$ \\
\hline Ce-144t & $1.00 E+00$ & $1.07 E-10$ & $7.10 \mathrm{E}-11$ & $8.64 E-11$ & $2.81 E-11$ \\
\hline$P m-147$ & $1.00 E+00$ & $1.07 E-10$ & $7.10 E-11$ & $8.64 E-11$ & $2.81 E-11$ \\
\hline Th-232 & $1.00 E+00$ & $1.07 E-10$ & $7.10 \mathrm{E}-11$ & $8.64 E-11$ & $2.81 E-11$ \\
\hline$U-234$ & $1.00 E+00$ & $1.07 E-10$ & $7.10 E-11$ & $8.64 E-11$ & $2.81 E-11$ \\
\hline U-235t & $1.00 E+00$ & $1.07 E-10$ & $7.10 \mathrm{E}-11$ & $8.64 E-11$ & $2.81 E-11$ \\
\hline$U-237$ & $1.00 E+00$ & 1.07E-10 & $7.10 E-11$ & $8.64 E-11$ & $2.81 E-11$ \\
\hline$U-238$ & $1.00 E+00$ & $1.07 E-10$ & $7.10 \mathrm{E}-11$ & $8.64 E-11$ & $2.81 E-11$ \\
\hline Np-239 & $1.00 E+00$ & 1.07E-10 & 7.10 E-11 & $8.64 E-11$ & $2.81 E-11$ \\
\hline$P u-238$ & $1.00 E+00$ & $1.07 E-10$ & $7.10 E-11$ & $8.64 E-11$ & $2.81 E-11$ \\
\hline Pu-239 & $1.00 E+00$ & $1.07 E-10$ & 7.10E-11 & $8.64 E-11$ & $2.81 E-11$ \\
\hline Am-241 & $1.00 E+00$ & $1.07 E-10$ & $7.10 E-11$ & $8.64 E-11$ & $2.81 E-11$ \\
\hline $\mathrm{Cm}-244$ & $1.00 E+00$ & $1.07 E-10$ & $7.10 E-11$ & $8.64 \mathrm{E}-11$ & $2.81 E-11$ \\
\hline
\end{tabular}

†Denotes preferred isotope when isotopic

breakdown is not available.

- Denotes value is either negative or above overall SRS release for that nuclide. 


\section{DOSE SUMMARY REPORT}

Dose to a Hypothetical Individual Living on the Savannah River 50-year CEDE (mrem)

\begin{tabular}{|cccc|c|}
\hline $\begin{array}{c}\text { Fish } \\
\text { Ingestion }\end{array}$ & $\begin{array}{c}\text { Water } \\
\text { Ingestion }\end{array}$ & $\begin{array}{c}\text { Shorotine } \\
\text { Exposure }\end{array}$ & $\begin{array}{c}\text { Swimming and } \\
\text { Boating }\end{array}$ & TOTAL \\
\hline $3.0 \mathrm{E}+00$ & $7.6 \mathrm{E}-01$ & $7.3 \mathrm{E}-03$ & $4.7 \mathrm{E}-05$ & $3.7 \mathrm{E}+00$ \\
\hline
\end{tabular}

Total Dose to the 50-Mile Population 50-year CEDE (person-rem)

\begin{tabular}{|cccc|c|}
\hline $\begin{array}{c}\text { Aquatic Foods } \\
\text { Consumption }\end{array}$ & $\begin{array}{c}\text { River } \\
\text { Recreation }\end{array}$ & $\begin{array}{c}\text { BJ Water } \\
\text { Consumption }\end{array}$ & $\begin{array}{c}\text { PW Water } \\
\text { Consumption }\end{array}$ & TOTAL \\
\hline $1.7 E+02$ & $3.1 E-01$ & $2.5 E+01$ & $9.2 E+00$ & $2.0 E+02$ \\
\hline
\end{tabular}


CONVERSION FACTORS

\begin{tabular}{|c|c|c|c|c|c|c|}
\hline Nuclide & $\begin{array}{l}\text { Decay } \\
\text { Constant } \\
(1 / \text { day }) \\
\end{array}$ & $\begin{array}{l}\text { Ingestion EDE } \\
\text { Dose Factor } \\
\text { (rem/uCi) }\end{array}$ & $\begin{array}{c}\text { Grd Shine DF } \\
\text { (mrem sq m) } \\
\text { (yr uCi) }\end{array}$ & $\begin{array}{l}\text { Water Im DF } \\
\text { (mrem cu m) } \\
\text { (yr uCi) }\end{array}$ & $\begin{array}{l}\text { Freshwater } \\
\text { Fish Accum. } \\
\text { Factor (L/kg) }\end{array}$ & $\begin{array}{c}\text { Saltwater } \\
\text { Invert Accum } \\
\text { Factor (L/kg) }\end{array}$ \\
\hline $\mathrm{H} \cdot 3$ & $1,54 E_{-04}$ & $6.3 E-05$ & $0.00 E+00$ & $0.00 E+00$ & $9.0 \mathrm{E} \cdot 01$ & $9.3 \mathrm{E} .01$ \\
\hline$P-32$ & $4.85 \mathrm{E}-02$ & 7,7 E 03 & $0.00 E+00$ & $0.00 E+00$ & $1.0 E+05$ & $3.0 E+04$ \\
\hline S-35 & $7.95 \mathrm{E}-03$ & $6.5=0.4$ & $0.00=000$ & $0.00 \mathrm{E}+00$. & $76=+02$ & 4.4E-01 \\
\hline Cr.51 & $2.50=-02$ & $1,3=0.6$ & $3,415+00$. & $3.47=-01$. & $2.0 \mathrm{C}+02$ & $20 E+03$ \\
\hline$M n-54$ & $2.22 \mathrm{E} \cdot 03$ & $2 t=00$ & $6.614+01$. & $9,42 E+00$. & $40 \mathrm{~F}+02$ & $4.0 E+02$ \\
\hline$C 0.58$ & $9.80 \mathrm{E}=08$ & $3.5 E 103$ & $9677=+01$. & \%, $09 \mathrm{E}+0 \%$ & $5.0 \mathrm{E}+01$ & $1.0 E+03$ \\
\hline Co -60 & $3.60 \mathrm{E} .0 .9$ & $2.6=02$ & $2.275+02$ & $6.78=+07$. & $50=+01$ & $1.0 E+0.3$ \\
\hline $\mathrm{Zn}-65$ & $2.845-083$ & $1,4=102$ & $5.485=09$. & $6.56 E+00 \%$ & $201=403$ & $5.0 E+04$ \\
\hline Sr-89 & $1.378=.02$ & $8 \% 7=0.03$ & 1.365 .09$. & $1.55=-05$. & $3.02+01$ & $2.0 E+01$ \\
\hline Sr.90 & $6.64 \mathrm{E} \cdot 05$. & $1 \%=00 \%$ & $0.00 \%+00$ & $0.00 \mathrm{E}+00$ & $30=+01$ & $2.0 E+01$ \\
\hline Y.91 & $1818=02$ & $8.91=08$. & $3.314=0.19$ & $4.06 \mathrm{E}-02$. & $2 \% 5=+104$ & $1.0 E+03$ \\
\hline Zr.95 & $1,08 \mathrm{a}=02$ & 6.410 .8 & $1,525+02$. & $8.24 \mathrm{E}+00$. & $3.3=400$ & $8.0 \mathrm{E}+01$ \\
\hline $\mathrm{Nb}-95$ & 1.9815 .02 & $3 \%=08$ & 7.765 .04$. & $8.50 E+00$ & $3.0=1.04$. & $1.0 \mathrm{E}+02$ \\
\hline Mo-99 & $2.52 \mathrm{E}-01$. & $4.4=0.3$ & $2.915 .0 \%$ & S.05E+00. & $10 \mathrm{E}+1$ & $1,0 E+01$ \\
\hline$R u-103$ & $1.26 \mathrm{~s}-02$ & $26=003$ & $5001=401$. & $5.26 \mathrm{E}+00$ & $10 \mathrm{OSO}$ & $1.0 E+03$ \\
\hline$R u-106$ & $888 \mathrm{e}-08$ & 2.18002 & $2,101=101$ & $2.28 \mathrm{E}+0.0$ & $10=+101$ & $1.0 E+03$ \\
\hline$S b-124$ & $1.15 \%=02$ & $9.38 \mathrm{y} 08$. & $1765=102$. & $2.15 E+01$. & $1.02 \mathrm{E}+00$ & $5.0 E+00$ \\
\hline Sb-125 & 7018.04 & $2.6=0.03$ & $4.48 \mathrm{E}+01$ & $4.63 E+00$ & $1.08+00$ & $5.0 E+00$ \\
\hline 1.129 & $2 / 1=10$ & $2.8 \mathrm{E}=0 \%$ & $2.20 \mathrm{E}+00$ & $1.07 \mathrm{E}-01 \%$ & $45=+01$ & $5.0 E+01$ \\
\hline $1-131$ & $8.62 \mathrm{E}=02$ & $5,3=02$ & $4.04 E+01$ & $4.17 E+00$ & $1 \% 5 \mathrm{E}+01$ & $5.0 E+01$ \\
\hline Cs-134 & $9.21 \mathrm{E}-04$ & $74 \mathrm{E}=2$ & $158 \mathrm{E}+00$ & $.170 \mathrm{E} .0 \%$ & $0.0=+08$ & $2.5 E+01$ \\
\hline Cs-137 & $6.29 \mathrm{E} \cdot 0$. & 5.0802 & $5.78 \mathrm{E}+0 \mathrm{H}$ & $6.22=+100$ & $0.00+03$ & $2.5 E+01$ \\
\hline $\mathrm{Ba}-140$ & $5.42 E-02$ & $8.4=106$ & $2.38 \mathrm{E}+02$ & $2.87=+01$ & $40 \mathrm{~L}+00$ & $1.0 E+02$ \\
\hline La-140 & $1.135=01$ & $\%+1=08$ & $2,13 \mathrm{E}+02$ & $2.66 \mathrm{E}, 01$ & $251=01$ & $10 E_{+} 03$ \\
\hline $\mathrm{Ce}-141$ & $2.183=02$ & $250=08$ & $8,781=+00$ & $8.71 / \mathrm{e} 011$ & 100100 & $6.0 E+02$ \\
\hline $\mathrm{Ce}-144$ & $2.448=00$ & 2,0402 & $5.10 E+00$ & $5.89 \mathrm{E} .07$ & $180 \mathrm{E}+00$ & $6.0 E+02$ \\
\hline$P m-147$ & $7.24=04$ & $9.5 \mathrm{e}=04$ & $4.10=2014$. & $4.15 \mathrm{E}-05$ & $2.5 \mathrm{C}+01$ & $1.0 E+03$ \\
\hline$T h-232$ & $1.35 \mathrm{~F}=1 \mathrm{~s}$ & $2.8 E+100$ & $6.66 \mathrm{E}-02$ & $2,26 \mathrm{E}-0,3$ & $3.0 \mathrm{c}+01$ & $2.0 E+03$ \\
\hline$U-234$ & $7,7 \% \mathrm{E}-09$ & $12.6=101$ & $8077=-82$ & $1,86 \mathrm{E}-03$ & $200+00$ & $1.0 E+01$ \\
\hline$U-235$ & $2.70 \mathrm{E} \cdot 12$ & $2.550 \%$ & $4.715+0 \%$ & $172 E+00$ & $20 E+00$ & $10 E+01$ \\
\hline$U \cdot 237$ & 1.603 E O1 & $2 \%=108$ & 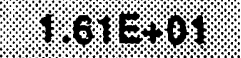 & $1,50 \mathrm{C}+0 \%$ & $2.0=100$ & $10 E+01$ \\
\hline$U-238$ & $4.2510=18$ & 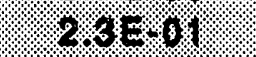 & 0.465 .80 & 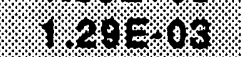 & $2=0=800$ & $1.0 \mathrm{E}+01$ \\
\hline Np-239 & $3.958-4019$ & $8,1=085$ & 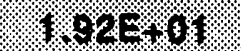 & $1.00 \mathrm{E}+0.0$ & 100507 & $100+01$ \\
\hline$P u-238$ & $2.18 \%=08$ & 580800 & $8.58650 \%$ & $1.122=-00$ & $8.5=800$ & $20 E+02$ \\
\hline Pu-239 & $7.87 \%=80$ & $4.3=100$ & $5,78=.02$ & $9: 7 / 4=804$ & $85 \% 1 \% 00$ & $2.0 E+02$ \\
\hline Am-241 & $4.890=00$ & 4501008 & $2.995+80$ & $2,8,5 \mathrm{E} .01$ & $2.5=101$ & $1.0 E+03$ \\
\hline $\mathrm{Cm}-244$ & $1.05 t=04$ & $2.35+100$ & $8.291 \mathrm{E} \quad 62$ & $672 \mathrm{E} 003$ & $2.5 E+01$ & $1.0 E+03$ \\
\hline
\end{tabular}


Dose to a Hypothetical Individual Living on the Savannah River 50-year CEDE (mrem)

\begin{tabular}{|ccccc|c|}
\hline $\begin{array}{c}\text { Fish } \\
\text { Inciestion }\end{array}$ & $\begin{array}{c}\text { Water } \\
\text { Ingestion }\end{array}$ & $\begin{array}{c}\text { Shoreline } \\
\text { Exposure }\end{array}$ & Swimming & Boating & $\begin{array}{c}\text { EDE (mrem) } \\
\text { Summed Over } \\
\text { All Nuclides }\end{array}$ \\
\hline $3.0 \mathrm{E}+00$ & $7.6 \mathrm{E}-01$ & $7.3 \mathrm{E}-03$ & $2.1 \mathrm{E}-05$ & $2.5 \mathrm{E}-05$ & $3.7 \mathrm{E}+00$ \\
\hline
\end{tabular}

\begin{tabular}{|c|c|c|c|c|c|c|}
\hline Nuclide & $\begin{array}{c}\text { Fish } \\
\text { Ingestion } \\
\text { Dose (mrem) }\end{array}$ & $\begin{array}{c}\text { Water } \\
\text { Ingestion } \\
\text { Dose (mrem) }\end{array}$ & $\begin{array}{c}\text { Shoreline } \\
\text { Dose } \\
\text { (mrem) }\end{array}$ & $\begin{array}{c}\text { Swimming } \\
\text { Dose } \\
(\mathrm{mr} \theta \mathrm{m})\end{array}$ & $\begin{array}{l}\text { Boating } \\
\text { Dose } \\
\text { (mrem) }\end{array}$ & $\begin{array}{c}\text { Nuclide Dose } \\
\text { All Pathways } \\
\text { (mrem) }\end{array}$ \\
\hline $\mathrm{H}-3$ & 1.2E-07 & 2.5E-06 & $0.0 E+00$ & $2.1 E-09$ & $0.0 E+00$ & $2.6 \mathrm{E}-06$ \\
\hline$P-32$ & $1.4 E+00$ & $2.8 E \cdot 04$ & $0.0 E+00$ & $0.0 E+00$ & $0.10 E+00$ & $1.4 E+00$ \\
\hline S.35 & 9.8E-04 & 2.6E-05 & $0.0 E+00$ & $0.0 E+00$ & $0.0 E+00$ & $1.0 E-03$ \\
\hline Cr-51 & 5.0E-05 & 5.0E-06 & 5.2E-07 & $3.7 E-08$ & $4.4 E-08$ & 5.6E-05 \\
\hline$M n-54$ & 2.2E-03 & $1.1 E-04$ & $1.5 E-04$ & $1.0 E-06$ & $1.2 E-06$ & $2.5 E \cdot 03$ \\
\hline Co-58 & $3.5 E-04$ & $1.4 E-04$ & $3.9 E-05$ & $1.2 E-06$ & $1.4 E-06$ & 5.3E-04 \\
\hline$C 0-60$ & 2.7E-J3 & $1.0 E-03$ & 2.5E-03 & $4.1 E-06$ & $4.9 E-06$ & $6.1 E-03$ \\
\hline $\mathrm{Zn} \cdot 65$ & 5.7E.02 & 5.5E-04 & $7.5 E-05$ & 7.1E-07 & $8.4 E-07$ & $5.7 E-02$ \\
\hline E 7.89 & 5.2E. 04 & $3.4 E-04$ & 3.8E-09 & $1.7 E-10$ & $2.0 E-10$ & 8.6E-04 \\
\hline S1. 90 & 8.0E-03 & 5.2E.03 & $0.0 E+00$ & $0.0 E+00$ & $0.0 E+00$ & 1.3E-02 \\
\hline$Y \cdot 91$ & $4.4 E-04$ & 3.5E-04 & 1.1E-07 & 4.4E-09 & 5.2E-09 & $7.9 E-04$ \\
\hline Zr-95 & 2.2E-05 & $1.3 E-04$ & 5.4E-05 & 8.9E-07 & 1.0E-06 & 2.1E-04 \\
\hline Nb-95 & $1.3 E-01$ & 8.5E-05 & $1.5 E-05$ & 9.2E.07 & $1.1 E-06$ & $1.3 E-01$ \\
\hline Mo-99 & 5.4E-05 & $1.2 E-04$ & $3.5 E-07$ & 2.6E-07 & $3.1 E-07$ & $1.7 E-04$ \\
\hline$R u-103$ & 5.3E-05 & 1.0E-04 & $1.1 E-05$ & 5.6E-07 & $6.7 E-07$ & $1.7 E-04$ \\
\hline$R u-106$ & $4.3 E-04$ & 8.3E-04 & $4.4 E-05$ & 2.5E-07 & 2.9E-07 & 1.3E-03 \\
\hline Sb-124 & $1.9 E-05$ & 3.6E-04 & 5.9E-05 & 2.3E-06 & $2.7 E-06$ & $4.5 E-04$ \\
\hline $\mathrm{Sb}-125$ & 5.3E-06 & $1.0 E-04$ & $2.5 E-04$ & $5.0 E-07$ & 6.0E-07 & $3.6 \mathrm{E}-04$ \\
\hline $1-129$ & 8.6E-03 & $1.1 \mathrm{E}-02$ & 1.3E-04 & $1.2 E-08$ & $1.4 E-08$ & 2.0E-02 \\
\hline $\mid-131$ & $1.4 E-03$ & 1.9E-03 & $1.7 E-06$ & 4.2E-07 & 4.9E-07 & 3.2E-03 \\
\hline Cs-134 & $4.5 \mathrm{E}-01$ & 2.9E-03 & $6.7 E-04$ & $1.9 E \cdot 06$ & 2.2E-06 & 4.6E-01 \\
\hline Cs-137 & 3.1 E-01 & 2.0E-03 & 2.2E-03 & 6.8E-07 & 8.0E-07 & $3.1 E-01$ \\
\hline $\mathrm{Ba}-140$ & 6.2E-05 & 3.1 E-04 & $1.6 \mathrm{E}-05$ & $3.0 E \cdot 06$ & 3.5E-06 & $3.9 E-04$ \\
\hline La-140 & $1.7 E-04$ & $1.6 \mathrm{E}-04$ & 1.3E-06 & $1.9 E-06$ & 2.3E-06 & $3.4 E-04$ \\
\hline $\mathrm{Ce}-141$ & 5.1E-06 & $1.0 \mathrm{E}-04$ & $1.6 \mathrm{E}-06$ & 9.3E-08 & $1.1 E-07$ & $1.1 E-04$ \\
\hline$C_{e-144}$ & 4.1E-05 & $7.9 E-04$ & 8.1 E-06 & $6.4 E-08$ & 7.6E-08 & $8.4 E-04$ \\
\hline Pm-147 & $4.8 E-05$ & $3.8 E-05$ & 2.2E-09 & $4.5 E-12$ & 5.3E-12 & $8.6 E-05$ \\
\hline Th-232 & $1.7 E-01$ & $1.1 E-01$ & $3.8 E-06$ & $2.5 E-10$ & $2.9 E-10$ & $2.8 E-01$ \\
\hline$U-234$ & $1.1 \mathrm{E}-03$ & $1.0 \mathrm{E}-02$ & 4.6E-06 & 2.0E-10 & $2.4 E-10$ & $1.1 E-02$ \\
\hline$U-235$ & $1.0 E-03$ & $9.9 E-03$ & 9.8E-04 & 1.9E-07 & 2.2E-07 & $1.2 E-02$ \\
\hline U-237 & 9.0E-06 & 9.2E-05 & 5.5E-07 & 1.5E-07 & $1.8 E-07$ & $1.0 E-04$ \\
\hline$U-238$ & $9.4 \mathrm{E}-04$ & $9.1 E-03$ & 3.7E-06 & $1.4 E-10$ & $1.7 E-10$ & 1.0E-02 \\
\hline Np-239 & 3.3E-05 & $7.4 E \cdot 05$ & $1.9 E-07$ & 1.5E-07 & $1.8 E-07$ & $1.1 E-04$ \\
\hline Pu-238 & $2.7 E-02$ & $1.5 \mathrm{E}-01$ & $4.2 E-06$ & $1.2 E-10$ & $1.4 E-10$ & $1.8 E-01$ \\
\hline $\mathrm{Pu}-239$ & 3.1 E-02 & 1.7 E-01 & 2.2E-06 & $1.1 E-10$ & $1.3 E-10$ & $2.0 E-01$ \\
\hline Am-241 & $2.3 E-01$ & $1.8 E-01$ & $1.7 E-04$ & $2.5 E-08$ & $3.0 E-08$ & $4.1 E-01$ \\
\hline $\mathrm{Cm}-244$ & $1.2 E-01$ & 9.1 E-02 & $2.4 E-06$ & $1.2 E-10$ & $1.4 E-10$ & $2.1 E-01$ \\
\hline
\end{tabular}




\section{Drinking Water Dose to Persons Using the Beaufort-Jasper and Port Wentworth Domestic Water Systems 50-year CEDE}

\begin{tabular}{|cc|cc|c|}
\hline $\begin{array}{c}\text { Max BJ User } \\
\text { (mrem) }\end{array}$ & $\begin{array}{c}\text { Max PW User } \\
\text { (mrem) }\end{array}$ & $\begin{array}{c}\text { BJ Users } \\
\text { (per-rem) }\end{array}$ & $\begin{array}{c}\text { PW Users } \\
\text { (per-rem) }\end{array}$ & $\begin{array}{c}\text { Pop. Dose } \\
\text { (Per-rem) } \\
\text { All Nuclides }\end{array}$ \\
\hline $9.9 \mathrm{E}-01$ & $1.2 \mathrm{E}+00$ & $2.5 \mathrm{E}+01$ & $9.2 \mathrm{E}+00$ & $3.4 E+01$ \\
\hline
\end{tabular}

\begin{tabular}{|c|c|c|c|c|c|}
\hline Nuclide & $\begin{array}{c}\text { Max. Dose to } \\
\text { BJ Users } \\
\text { (mrem) }\end{array}$ & $\begin{array}{l}\text { Max. Dose to } \\
\text { PW Users } \\
\text { (mrem) }\end{array}$ & $\begin{array}{c}\text { BJ Users } \\
\text { Pop. Dose } \\
\text { (person-rem) }\end{array}$ & $\begin{array}{c}\text { PW Users } \\
\text { Pop. Dose } \\
\text { (person-rem) }\end{array}$ & $\begin{array}{l}\text { Total Water } \\
\text { Pop. Dose } \\
\text { (person-rem) }\end{array}$ \\
\hline $\mathrm{H} \cdot 3$ & 3.3E.06 & 4.0E-06 & 8.3E-05 & 3.0E-05 & $1.1 \mathrm{E}-04$ \\
\hline P-32 & 4.0E-04 & 4.9E-04 & 1.0E-02 & 3.7E-03 & $1.4 E-02$ \\
\hline S-35 & 3.4E-05 & 4.1E-05 & $8.5 E-04$ & $3.1 E-04$ & $1.2 E-03$ \\
\hline Cr.51 & 6.7E-06 & 8.2E-06 & $1.7 E-04$ & 6.2E-05 & 2.3E-04 \\
\hline$M n-54$ & $1.4 E-04$ & $1.7 E-04$ & 3.5E-03 & 1.3E-03 & $4.8 E-03$ \\
\hline Co-58 & $1.8 E-04$ & 2.2E-04 & 4.6E-03 & 1.7E-03 & $6.3 E-03$ \\
\hline Co-60 & 1.3E-03 & $1.6 \mathrm{E}-03$ & $3.4 E-02$ & 1.2E.02 & 4.7E-02 \\
\hline $2 n-65$ & 7.3E-04 & 8.8E-04 & $1.8 E-02$ & 6.7E-03 & $2.5 E-02$ \\
\hline Sr-89 & $4.5 E-04$ & 5.5E-04 & $1.1 E-02$ & $4.2 E-03$ & $1.6 E-02$ \\
\hline Sr.90 & 6.7E-03 & 8.2E-03 & $1.7 E-01$ & $6.2 E-02$ & 2.3E-01 \\
\hline Y.91 & $4.6 E-04$ & 5.6E-04 & $1.2 E-02$ & 4.3E-03 & $1.6 \mathrm{E}-02$ \\
\hline Zr-95 & $1.8 E-04$ & 2.1E-04 & $4.5 E-03$ & 1.6E-03 & $6.1 E-03$ \\
\hline Nb-95 & 1.1E-04 & $1.4 E-04$ & $2.9 E-03$ & $1.1 E-03$ & $3.9 E-03$ \\
\hline Mo-99 & 2.3E-04 & 2.8E-04 & 5.8E-03 & $2.1 E-03$ & $7.9 E-03$ \\
\hline$R u-103$ & $1.4 E-04$ & $1.7 E-04$ & $3.5 E-03$ & 1.3E-03 & $4.8 E-03$ \\
\hline$R u-106$ & $1.1 E-03$ & $1.3 E-03$ & 2.8E-02 & 1.0E-02 & $3.8 E-02$ \\
\hline Sb-124 & $4.8 E-04$ & 5.9E-04 & 1.2E-02 & $4.5 E-03$ & $1.7 E-02$ \\
\hline$S b-125$ & $1.3 E-04$ & $1.6 \mathrm{E}-04$ & $3.4 E-03$ & $1.2 E-03$ & 4.7E-03 \\
\hline $1-129$ & $1.5 \mathrm{E}-02$ & $1.8 E-02$ & 3.7E-01 & 1.3E-01 & 5.0E-01 \\
\hline 1.131 & 2.7E-03 & 3.3E-03 & $7.0 E-02$ & 2.5E-02 & 9.5E-02 \\
\hline Cs-134 & $3.8 E-03$ & 4.7E-03 & 9.7E-02 & 3.5E-02 & 1.3E-01 \\
\hline Cs-137 & 2.6E-03 & 3.2E-03 & 6.6E-02 & 2.4E-02 & 9.0E-02 \\
\hline $\mathrm{Ba}-140$ & $4.4 E-04$ & 5.3E.04 & 1.1 E-02 & 4.0E-03 & 1.5E-02 \\
\hline La-140 & $4.0 E-04$ & 4.9E-04 & 1.0E-02 & 3.7E-03 & $1.4 E-02$ \\
\hline $\mathrm{Ce}_{e-141}$ & 1.3E-04 & $1.6 \mathrm{E}-04$ & $3.4 E-03$ & $1.2 E-03$ & 4.7E-03 \\
\hline$C e-144$ & 1.0E-03 & 1.3E-03 & 2.6E-02 & $9.6 \mathrm{E}-03$ & 3.6E-02 \\
\hline Pm-147 & 4.9E-05 & 6.0E-05 & 1.2E-03 & 4.6E-04 & $1.7 E-03$ \\
\hline Th-232 & $1.5 E-01$ & $1.8 E-01$ & $3.7 E+00$ & $1.3 E+00$ & $5.0 E+00$ \\
\hline$U-234$ & 1.3E-02 & 1.6E-02 & $3.4 E-01$ & 1.2E-01 & 4.7E-01 \\
\hline$U \cdot 235$ & 1.3E-02 & $1.6 E-02$ & 3.3E-n1 & 1.2E-01 & $4.5 E-01$ \\
\hline$U .237$ & $1.4 E-04$ & $1.7 E-04$ & $3.5 E-03$ & 1.3E-03 & $4.8 E-03$ \\
\hline$U-238$ & 1.2E-02 & 1.5E-02 & 3.0E-01 & $1.1 \mathrm{E}-01$ & $4.1 E-01$ \\
\hline$N p-239$ & 1.5 E-04 & $1.8 E-04$ & 3.8E-03 & $1.4 \mathrm{E} \cdot 03$ & 5.2E-03 \\
\hline$P u-238$ & 2.0E-01 & 2.4 E-01 & $5.0 E+00$ & $1.8 E+00$ & $6.8 E+00$ \\
\hline$P u-239$ & 2.2E-01 & 2.7E-01 & $5.6 E+00$ & $2.1 E+00$ & $7.7 E+00$ \\
\hline Am-241 & 2.3E-01 & 2.8E-01 & $5.9 E+00$ & $2.2 E+00$ & $8.1 E+00$ \\
\hline $\mathrm{Cm}-244$ & 1.2E-01 & $1.5 E-01$ & $3.0 E+00$ & $1.1 E+00$ & $4.1 E+00$ \\
\hline
\end{tabular}




\section{Aquatic Foods Ingestion and Recreational Dose to the 50-Mile Population 50-year CEDE (person-rem)}

\begin{tabular}{|c|c|c|c|c|c|c|}
\hline $\begin{array}{l}\text { Sport Fish } \\
\text { Ingestion } \\
4.6 E+00\end{array}$ & $\begin{array}{c}\text { Comm. Fish } \\
\text { Ingestion } \\
3.3 E-01 \\
\end{array}$ & $\begin{array}{c}\begin{array}{c}\text { Invertebrate } \\
\text { Ingestion }\end{array} \\
1.6 \mathrm{E}+02\end{array}$ & $\frac{\text { Shoreline }}{3.0 \text { E-01 }}$ & $\frac{\text { Swimming }}{3.8 \mathrm{E}-04}$ & $\frac{\text { Boating }}{1.3 \mathrm{E}-03}$ & \begin{tabular}{|c|}
$50 \mathrm{mi}$ Pop Dose \\
(Person-rem) \\
All Nuclides \\
$1.7 \mathrm{E}+02$ \\
\end{tabular} \\
\hline Nuclide & $\begin{array}{c}\text { Sport Fish } \\
\text { Ingestion } \\
\text { EDE }\end{array}$ & $\begin{array}{c}\text { Comm Fish } \\
\text { Ingestion } \\
\text { EDE }\end{array}$ & $\begin{array}{c}\text { Invertebrate } \\
\text { Ingestion } \\
\text { EDE }\end{array}$ & $\begin{array}{c}\text { Shoreline } \\
\text { Exposure } \\
\text { EDE }\end{array}$ & $\begin{array}{c}\text { Swimming } \\
\text { EDE }\end{array}$ & $\begin{array}{c}\text { Boating } \\
\text { EDE }\end{array}$ \\
\hline$\overline{H-3}$ & 2.1E-07 & $1.6 \mathrm{E}-08$ & $6.4 E \cdot 07$ & $0.0 E+00$ & $3.8 \mathrm{E}-08$ & $0.0 E+00$ \\
\hline$P-32$ & $1.8 E+00$ & 1.2E-01 & $1.3 E+00$ & $0.0 E+00$ & $0.0 E+00$ & $0.0 E+00$ \\
\hline S-35 & 1.7E-03 & 1.3E-04 & 2.8E-06 & $0.0 E+00$ & $0.0 E+00$ & $0.0 E+00$ \\
\hline Cr.51 & 7.6E-05 & 5.4E-06 & 2.1E-03 & 2.2E-05 & 6.6E-07 & 2.3E-06 \\
\hline$M n-54$ & 4.0E-03 & $3.0 E \cdot 04$ & 1.2E-02 & 6.2E-03 & 1.8E-05 & $6.3 E-05$ \\
\hline Co.58 & 6.0E-04 & 4.5E-05 & 3.4E-02 & $1.6 E-03$ & 2.1'E-05 & ?.3E-05 \\
\hline Co-60 & 4.9E-03 & 3.8E-04 & 2.8E-01 & $1.0 E-01$ & $7.4 E-05$ & 2.5E-04 \\
\hline$Z n-65$ & $1.0 \mathrm{E}-01$ & 7.8E-03 & $7.4 E+00$ & 3.1E-03 & 1.3E-05 & $4.4 E-05$ \\
\hline Sr-89 & 8.6E-04 & 6.3E-05 & 1.6E-03 & 1.6E-07 & 3.0E-09 & $1.0 E \cdot 08$ \\
\hline Sr-90 & 1.5E-02 & $1.1 E \cdot 03$ & 2.8E-02 & $0.0 E+00$ & $0.0 E+00$ & $0.0 E+00$ \\
\hline$Y-91$ & $7.4 E-04$ & 5.5E.05 & 8.4E-02 & 4.5E-06 & 7.9E-08 & $2.7 \mathrm{E}-07$ \\
\hline$Z r-95$ & 3.8E-05 & 2.8E-06 & 2.6E-03 & 2.3E-03 & $1.6 E-05$ & $5.5 E-05$ \\
\hline Nb-95 & 2.0E-01 & 1.5E-02 & $1.9 E-03$ & $6.3 E \cdot 04$ & $1.6 \mathrm{E}-05$ & 5.7E-05 \\
\hline Mo.99 & 1.3E-05 & 4.8E-07 & 1.8E-05 & $1.5 E-05$ & 4.7E-06 & $1.6 E \cdot 05$ \\
\hline$R u-103$ & 8.5E-05 & 6.2E-06 & 2.4E-02 & 4.6E-04 & $1.0 \mathrm{E}-05$ & $3.5 E-05$ \\
\hline$R u-106$ & 7.7E-04 & 5.9E-05 & 2.2E-01 & $1.8 E-03$ & 4.5E-06 & $1.5 E-05$ \\
\hline $\mathrm{Sb}-124$ & 3.1 E-05 & 2.3E-06 & 4.4E-04 & 2.5E-03 & 4.2E-05 & $1.4 E-04$ \\
\hline $\mathrm{Sb}-125$ & 9.7E-06 & 7.5E-07 & 1.4E-04 & $1.0 \mathrm{E}-02$ & 9.1E-06 & 3.1E-05 \\
\hline $1-129$ & 1.6E-02 & $1.2 E-03$ & $1.5 \mathrm{E}-01$ & 5.2E-03 & $2.1 \mathrm{E}-07$ & 7.2E-07 \\
\hline $1-131$ & 1.3E-03 & 7.5E-05 & 9.5E-03 & 7:0E-05 & 7.5E-06 & $2.6 \mathrm{E}-05$ \\
\hline Cs-134 & 8.3E-01 & 6.4E-02 & 2.0E-02 & 2.8E-02 & $3.4 E-05$ & $1.2 \mathrm{E}-04$ \\
\hline Cs-137 & 5.6E-01 & 4.3E-02 & $1.4 E-02$ & 9.0E-02 & 1.2E-05 & 4.2E-05 \\
\hline $\mathrm{Ba}-140$ & 7.3E-05 & 4.8E-06 & 4.6E-03 & 6.6E-04 & 5.3E-05 & $1.8 E-04$ \\
\hline La-140 & 1.2E-05 & 2.6E-07 & 3.9E-04 & 5.6E-05 & 3.5E-05 & $1.2 E-04$ \\
\hline $\mathrm{Ce}_{0-141}$ & 7.9E-06 & 5.7E-07 & 1.3E-02 & 6.6E-05 & 1.7E-06 & 5.7E.06 \\
\hline$C_{\theta}-144$ & 7.3E-05 & 5.6E-06 & 1.3E-01 & $3.4 E-04$ & 1.2E-06 & 4.0E-06 \\
\hline$P m-147$ & 8.9E-05 & 6.8E.06 & 1.0E-02 & 9.2E-08 & $8.1 E-11$ & $2.8 E-10$ \\
\hline Th-232 & 3.2E-01 & 2.4E-02 & $6.1 E+01$ & 1.6E-04 & 4.4E-09 & $1.5 E-08$ \\
\hline$U-234$ & 2.0E-03 & 1.5E-04 & 2.9E-02 & $1.9 E-04$ & 3.6E-09 & 1.3E-08 \\
\hline$U-235$ & $1.9 E-03$ & $1.4 E \cdot 04$ & 2.7E-02 & 4.1E-02 & $3.4 E-06$ & $1.2 E-05$ \\
\hline$U-237$ & 7.2E-06 & 4.1E-07 & 7.8E-05 & 2.3E-05 & 2.7E-06 & $9.3 E-06$ \\
\hline$U-238$ & $1.7 E-03$ & 1.3E-04 & 2.5E-02 & 1.5E-04 & 2.5E.09 & 8.7E-09 \\
\hline Np-239 & 5.7E-06 & $1.8 E-07$ & $6.9 E-06$ & 7.9E-06 & 2.8E-06 & $9.5 E-06$ \\
\hline$P u-238$ & 5.0E-02 & $3.9 E-03$ & $8.3 E+00$ & $1.8 E-04$ & 2.2E-09 & $7.6 \mathrm{E} \cdot 09$ \\
\hline$P u-239$ & 5.7E-02 & $4.4 E-03$ & $9.4 E+00$ & 9.0E-05 & $1.9 E-09$ & $6.6 \mathrm{E}-09$ \\
\hline Am-241 & 4.2E-01 & 3.3E-02 & $4.9 E+01$ & $6.9 E-03$ & 4.6E-07 & $1.6 E-06$ \\
\hline $\mathrm{Cm}-244$ & 2.2E-01 & $1.7 E-02$ & $2.5 E+01$ & $1.0 E-04$ & 2.1E-09 & $7.2 E-09$ \\
\hline
\end{tabular}


APPENDIX B

Hand Calculations of LADTAP XL Benchmark 


\section{LADTAP XL}

\section{Benchmarking Calculations}

A Total 50-Mile Fish Consumption = (Pop Fish Usage) (50-Mile Pop)

$=(9)(555,100)=5.0 \times 10^{6} \mathrm{~kg} / \mathrm{yr}$

B Total 50-Mile Invert. Consumption = (Pop. Invert. Usage) (50-Mile Pop)

$=(2)(555,100)=1.1 \times 106 \mathrm{~kg} / \mathrm{yr}$

C River Concentration using given flow rate $(\mu \mathrm{Ci} / \mathrm{ml})$ :

301 CONC. $=\underline{\text { Unit Release }}\left(1.12 \times 10^{-6} \mathrm{yr} \mu \mathrm{Ci} \mathrm{ft} / \mathrm{sec} \mathrm{Ci} \mathrm{ml}\right)$ 301 flow

$$
=(1 / 10426) \cdot\left(1.12 \times 10^{-6}\right)=1.07 \times 10^{-10} \mu \mathrm{Ci} / \mathrm{ml}
$$

D River concentration at Beaufort-Jasper water intake $(\mu \mathrm{Ci} / \mathrm{ml})$ :

BJ CONC $=$ Unit Release $\left(1.12 \times 10^{-6} \mathrm{yr} \mu \mathrm{Ci} \mathrm{ft}{ }^{3} / \mathrm{sec} \mathrm{Ci} \mathrm{ml}\right)$ BJ flow

$$
=(1 / 15775) \cdot\left(1.12 \times 10^{-6}\right)=7.10 \times 10^{-11} \mu \mathrm{Ci} / \mathrm{ml}
$$

E River concentration at Port Wentwort water intake $(\mu \mathrm{Ci} / \mathrm{ml})$ :

PW CONC $=$ Unit Release $\left(1.12 \times 10^{-6} \mathrm{yr} \mu \mathrm{Ci} \mathrm{fi} / \mathrm{sec} \mathrm{Ci} \mathrm{ml}\right)$ PW flow

$$
=(1 / 12958) \cdot\left(1.12 \times 10^{-6}\right)=8.64 \times 10^{-11} \mu \mathrm{Ci} / \mathrm{ml}
$$

F River concentration at the Savannah River estuary $(\mu \mathrm{Ci} / \mathrm{ml})$ :

$$
\begin{aligned}
\text { EST CONC } & =\frac{\text { Unit Release }\left(1.12 \times 10^{-6}{\mathrm{yr} . \mu \mathrm{Ci} . \mathrm{ft}^{3}}^{3} / \mathrm{sec}\right. \text { Ci.ml) }}{\text { (estuary flow) (dilution) }} \\
& =\left(1 \cdot 1.12 \times 10^{-6}\right) /(13270 \cdot 3)=2.81 \times 10^{-11} \mu \mathrm{Ci} / \mathrm{ml}
\end{aligned}
$$


G Individual dose from fish ingestion:

Dose $=($ MI fish usage $)(301$ CONC) (ingestion DF) $(\mathrm{FW}$ fish accum.) (transport decay) (106 $\mathrm{ml} \mathrm{mrem} / \mathrm{L}$ rem)

$=1.15 \times 10^{-7}$ mrem $\left({ }^{3} \mathrm{H}\right)$

H Individual dose from water ingestion:

Dose $=(301 \mathrm{CONC})(\mathrm{MI}$ water usage $)($ ingestion DF $)\left(10^{6} \mathrm{ml} \mathrm{mrem} / \mathrm{L} \mathrm{rem}\right)$ (transport decay)

$=2.49 \times 10^{-6}\left({ }^{3} \mathrm{H}\right)$

I Individual dose from shoreline exposure:

Dose $=$ (water-to-sediment transfer coeff.) (MI shoreline usage) (shorewidth factor) (301 CONC) (transport decay) (nuclide half-life) (ground shine DF) (exponential buildup over plant lifetime $) /(8760 \mathrm{hrs} / \mathrm{yr})$

$=\left(100 \mathrm{~L} / \mathrm{m}^{2}\right.$ day $)(23 \mathrm{hrs})(0.2)\left(1.07 \times 10^{-10}, \mu \mathrm{Ci} / \mathrm{ml}\right)$ $\left(e^{\left.-\left(6.29 \times 10^{-5}\right)(1 \text { day })\right)}(1000 \mathrm{ml} / \mathrm{L})\left(0.693 / 6.29 \times 10^{-5}\right.\right.$ day $\left.^{-1}\right)$

$\left(57.8 \mathrm{mrem} \mathrm{m}^{2} / \mathrm{yr} \mu \mathrm{Ci}\right) \quad\left[1-\mathrm{e}^{-\left(\left(6.29 \times 10^{-5}\right) 40 \cdot 365\right]}\right.$

$=2.15 \times 10^{-3} \mathrm{mrem}\left({ }^{137} \mathrm{Cs}\right)$

J Individual dose from exposure while swimming:

All Nuclides Except Tritium:

Dose $=(301$ CONC) (transport decay) (MI swimming usage) (water immer. DF) $\left(114.2 \mathrm{ml} \mathrm{yr} / \mathrm{m}^{3} \mathrm{hr}\right) /($ GEOM)

$=\left(1.07 \times 10^{-10} \mu \mathrm{Ci} / \mathrm{ml}\right)\left(\mathrm{e}^{\left.-\left(6.29 \times 10^{-5}\right)(1)\right)(8.9 \mathrm{hrs})(622 \mathrm{mrem} \mathrm{m} 3 / \mathrm{yr} \mu \mathrm{Ci})}\right.$ $(114.2) / 1$

$=6.76 \times 10^{-7} \mathrm{mrem}\left({ }^{137} \mathrm{Cs}\right)$

Tritium Only:

Dose $=($ absorption rate $)($ ingestion DF) $($ submersion duration $)(301 \mathrm{CONC})$

$=(1000 \mathrm{mrem} / \mathrm{rem})(35 \mathrm{ml} / \mathrm{hr})\left(6.3 \times 10^{-5} \mathrm{rem} / \mu \mathrm{Ci}\right)(8.9 \mathrm{hrs})$

$\left(1.07 \times 10^{-10} \mu \mathrm{Ci} / \mathrm{ml}\right)$

$=2.10 \times 10^{-9}$ mrem $\left({ }^{3} \mathrm{H}\right)$ 
$\mathbf{K}$ Individual dose from exposure while boating:

Dose $=(301 \mathrm{CONC})$ (transport decay) (MI boating usage) (water immer. DF) $\left(114.2 \mathrm{ml} \mathrm{yr} / \mathrm{m}^{3} \mathrm{hr}\right) /($ GEOM)

$$
\left.=\left(1.07 \times 10^{-10} \mu \mathrm{Ci} / \mathrm{ml}\right)\left(e^{-\left(6.29 \times 10^{-5}\right.}\right)(1)\right)(21 \mathrm{hrs})
$$

$\left(6.22 \mathrm{mrem} \mathrm{m}^{3} / \mathrm{yr} \mu \mathrm{Ci}\right)(114.2) / 2$

$=7.98 \times 10^{-7} \mathrm{mrem}\left({ }^{137} \mathrm{Cs}\right)$

L Maximum dose to Beaufort-Jasper individual via water ingestion:

Dose $=(\mathrm{BJ}$ CONC) (transport decay) (max water consumption) (ingestion DF) $\left(10^{6} \mathrm{ml} \mathrm{mrem} / \mathrm{L} \mathrm{rem}\right)$

$=\left(7.10 \times 10^{-11} \mu \mathrm{Ci} / \mathrm{ml}\right)\left(\mathrm{e}^{\left.-\left(1.54 \times 10^{-4}\right)(4)\right)(730 \mathrm{~L} / \mathrm{yr})}\right.$

$\left(6.3 \times 10^{-5} \mathrm{rem} / \mu \mathrm{Ci}\right)(106)$

$=3.27 \times 10^{-6} \mathrm{mrem}\left({ }^{3} \mathrm{H}\right)$

M Maximum dose to Port Wentworth individual via water ingestion:

Dose $=(\mathrm{PW}$ CONC) (transport decay) (max water consumption) (ingestion DF) $\left(10^{6} \mathrm{ml} \mathrm{mrem} / \mathrm{L} \mathrm{rem}\right)$

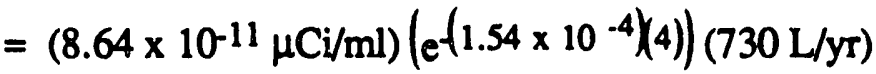

$\left(6.3 \times 10^{-5} \mathrm{rem} / \mu \mathrm{Ci}\right)\left(10^{6}\right)$

$=3.97 \times 10^{-6}$ mrem $\left({ }^{3} \mathrm{H}\right)$

N Population dose to Beaufort-Jasper water users:

Dose $=(\mathrm{BJ}$ CONC) $($ transport decay) (avg water consumption) (ingestion DF) (population) $\left(10^{3} \mathrm{ml} / \mathrm{L}\right)$

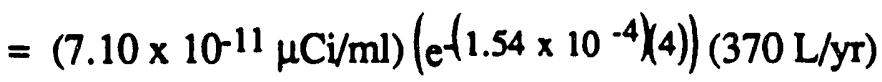

$\left(6.3 \times 10^{-5} \mathrm{rem} / \mu \mathrm{Ci}\right)(50,000$ persons $)\left(10^{3}\right)$

$=8.28 \times 10^{-5}$ person-rem $\left({ }^{3} \mathrm{H}\right)$ 
O Population dose to Port Wentworth water users:

Dose $=(\mathrm{PW}$ CONC) $($ transport decay $)($ avg water consumption $)$ (ingestion DF) (population) $\left(10^{3} \mathrm{ml} / \mathrm{L}\right)$

$=\left(8.64 \times 10^{-11} \mu \mathrm{Ci} / \mathrm{ml}\right)\left(\mathrm{e}^{\left.\left(1.54 \times 10^{-4}\right)(4)\right)(370 \mathrm{~L} / \mathrm{yr})}\right.$

$\left(6.3 \times 10^{-5} \mathrm{rem} / \mu \mathrm{Ci}\right)(15,000$ persons $)\left(10^{3}\right)$

$=3.02 \times 10^{-5}$ person-rem $\left({ }^{3} \mathrm{H}\right)$

P Total population dose via drinking water:

Dose $=$ BJ Dose + PW Dose

$=8.28 \times 10^{-5}+3.02 \times 10^{-5}=1.13 \times 10^{-4}$ person-rem $\left({ }^{3} \mathrm{H}\right)$.

Q 50-Mile population dose from sport fish harvest:

Dose $=(301 \mathrm{CONC})$ (transport decay) (FW fish accum) (harvest) (ingestion DF) $\left(10^{3} \mathrm{~m} / \mathrm{L}\right)$

$\left.=1.07 \times 10^{-10} \mu \mathrm{Ci} / \mathrm{ml}\right)\left(\mathrm{e}^{\left.-\left(1.54 \times 10^{-4}\right)(10)\right)(0.9 \mathrm{~L} / \mathrm{kg})}\right.$

$\left(3.5 \times 10^{4} \mathrm{~kg} / \mathrm{yr}\right)\left(6.3 \times 10^{-5} \mathrm{rem} / \mu \mathrm{Ci}\right)\left(10^{3}\right)$

$=2.12 \times 10^{-7} \mathrm{rem}\left({ }^{3} \mathrm{H}\right)$

Where HARVEST = The lesser of the actual Savannah River harvest and the total 50-mile fish consumption.

$\therefore$ HARVEST $=\operatorname{Min}\left(3.5 \times 10^{4} ; 5.0 \times 10^{6}\right)$

R 50-Mile population dose from commercial fish harvest:

DOSE $=(301$ CONC) (transport decay) (FW fish accum.) (harvest) (ingestion DF) $\left(10^{3} \mathrm{ml} / \mathrm{L}\right)$

$$
\begin{aligned}
& \left.=1.07 \times 10^{-10} \mu \mathrm{Ci} / \mathrm{ml}\right)\left(\mathrm{e}^{\left.-\left(1.54 \times 10^{-4}\right)(13)\right)(0.9 \mathrm{~L} / \mathrm{kg})}\right. \\
& \left(2.7 \times 10^{3} \mathrm{~kg} / \mathrm{yr}\right)\left(6.3 \times 10^{-5} \mathrm{rem} / \mu \mathrm{Ci}\right)\left(10^{3}\right) \\
& =1.64 \times 10^{-8} \mathrm{rem}\left({ }^{3} \mathrm{H}\right)
\end{aligned}
$$

Where HARVEST $=$ the lesser of the actual Savannah River commercial harvest and the difference between the total 50-mile fish consumption and the actual sport harvest.

$\therefore \quad$ HARVEST $=\operatorname{Min}\left(2.7 \times 10^{3} ; 5.0 \times 10^{6}-3.5 \times 10^{4}\right)$ 
S 50-Mile population dose from saltwater invertebrate harvest:

Dose $=($ EST CONC) (transport decay)(SW invert. accum) (harvest) (ingestion DF) $\left(10^{3} \mathrm{ml} / \mathrm{L}\right)$

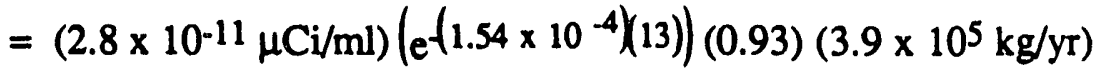

$$
\begin{aligned}
& \left(6.3 \times 10^{-5} \mathrm{rem} / \mu \mathrm{Ci}\right)\left(10^{3}\right) \\
& =6.42 \times 10^{-7} \mathrm{rem}\left({ }^{3} \mathrm{H}\right)
\end{aligned}
$$

Where HARVEST = the lesser of the actual Savannah River invertebrate harvest and the total 50 mile invertebrate consumption.

$\therefore$ HARVEST $=\operatorname{Min}\left(3.9 \times 10^{5} ; 1.1 \times 10^{6}\right)$

T 50-Mile population dose from shoreline exposure:

Dose $=($ transfer coeff.) (pop shoreline usage) (shorewidth factor) $(301 \mathrm{CONC})$ (transport decay) (nuclide half-life) (ground shine DF) (buildup over plant lifetime) / ( $8760 \mathrm{hrs} / \mathrm{yr}$ )

$=\left(100 \mathrm{~L} / \mathrm{m}^{2}\right.$ day $)\left(9.6 \times 10^{5}\right.$ person hrs $)(0.2)\left(1.07 \times 10^{-10} \mu \mathrm{Ci} / \mathrm{ml}\right)$ $\left(\mathrm{e}^{\left.-\left(6.29 \times 10^{-5}\right)(1)\right)\left(0.693 / 6.29 \times 10^{-5} \mathrm{~d}^{-1}\right)\left(57.8 \mathrm{mrem} \mathrm{m}^{2} / \mathrm{yr} \mu \mathrm{Ci}\right)}\right.$ $\left[1-e^{\left.-\left(6.29 \times 10^{-5}\right) 40 \cdot 365\right]}\right] / 8760$

$=8.97 \times 10^{-2}$ person-rem $\left({ }^{137} \mathrm{Cs}\right)$

U 50-Mile population dose from exposure while swimming:

\section{All Nuclides Except Tritium:}

Dose $=(301$ CONC) (transport decay) (pop swimming usage) (water immer. DF) ( $\left.0.1142 \mathrm{ml} \mathrm{yr} \mathrm{rem} / \mathrm{m}^{3} \mathrm{hr} \mathrm{mrem}\right) /($ GEOM)

$=\left(1.07 \times 10^{-10} \mu \mathrm{Ci} / \mathrm{ml}\right)\left(\mathrm{e}-\left(6.29 \times 10^{-5}\right)(1)\right)\left(1.6 \times 10^{5}\right.$ person hrs $)$ (6.22 $\left.\mathrm{mrem} \mathrm{m}^{3} / \mathrm{yr} \mu \mathrm{Ci}\right)(0.1142) / 1$

$=1.21 \times 10^{-5}$ person-rem $\left({ }^{137} \mathrm{Cs}\right)$

Tritium Only:

$$
\begin{aligned}
\text { Dose }= & (\text { absorption rate) (ingestion DF) (population usage) }(301 \mathrm{CONC}) \\
= & (35 \mathrm{ml} / \mathrm{hr})\left(6.3 \times 10^{-5} \mathrm{rem} / \mu \mathrm{Ci}\right)\left(1.6 \times 10^{5} \text { person-hrs }\right) \\
& \left(1.07 \times 10^{-10} \mu \mathrm{Ci} / \mathrm{ml}\right) \\
= & 3.77 \times 10^{-8} \text { person-rem }\left({ }^{3} \mathrm{H}\right)
\end{aligned}
$$


V 50-Mile population dose from exposure while boating:

Dose $=(301 \mathrm{CONC})$ (transport decay) $($ pop boating usage) $($ water immer. DF) $\left(0.1142 \mathrm{ml} \mathrm{yr} \mathrm{rem} / \mathrm{m}^{2} \mathrm{hr}\right.$ mrem) / (GEOM)

$=\left(1.07 \times 10^{-10} \mu \mathrm{Ci} / \mathrm{ml}\right)\left(\mathrm{e}-\left(6.29 \times 10^{-5}\right)(1)\right)\left(1.1 \times 10^{6}\right.$ per hrs $)$ $\left(6.22 \mathrm{mrem} \mathrm{m}^{3} / \mathrm{yr} \mu \mathrm{Ci}\right)(0.1142) / 2$

$=4.18 \times 10^{-5}$ person-rem $\left({ }^{137} \mathrm{Cs}\right)$ 


\section{APPENDIX C}

Savannah River Flow Rates for Prospective Dose Assessments 
SRLETS-910257

WESTINGHOUSE SAVANNAH RIVER COMPANY
SAVANNAH RIVER LABORATORY

June 10, 1991

To: $\quad$ A.L. Boni, 773A

From: D.W. Hayes, 773A Dutaye

HISTORICAL RIVER FLOW RATES FOR DOSE CALCULATIONS

SUMMARY

Annual average river flow rates are required input to the LADTAP Computer Code for River. The source of information on annual of radioactive materials to the Savannah varies, depending on whether calculations are for flow rates used in dose calculations releases. Examples of these types of releases are: Retrospective - releases from routine operations (annual environmental reports)
and short term release incidents that have occurred. Prospective - releases that might be expected in the future from routine or abnormal
operation of existing or new facilities (EIS's, EID's, SAR's, etc.)

This memorandum provides historical flow rates at the downstream gauging station at Heaufort-Jasper and in retrospective dose calculations and derives flow rate data for the calculations, an average flow rate of 10,500 cfs is estabt plants. For prospective (Highway 301) and a derived flow rate 13,000 established for maximum individuals Wentworth water treatment plants. Minimum anns for the Beaufort-Jasper and Port from routine operations, are 5,300 cfs and am annual flow rates, for maximizing doses maximum individual and water trea cts and a derived flow rate of 6,600 cfs for the rates for calculation of prospective doses plants, respectively. The minimum daily flow and a derived flow rate of $4,900 \mathrm{cfs}$ for the short-term release incidents are 3,900 cfs plants, respectively.

\section{INTRODUCTION}

The LADTAP computer code is used for calculating doses to individuals and population River. Annual river flow rate datine releases of radioactive materials to the Savannah dilution of the released materials. The source input to the code in order to calculate used in dose calculations varies, depending on information on annual river flow rates releases (i.e., releases have occurred in the past) or prolculations are for retrospective releases that might be expected in the future). Examples of the releases (hypothetical and short term release incidents operations (annual environmental reports) 
Prospective - releases that might be expected in the future from routine or abnormal operation of existing or new facilities (EIS's, EID's, SAR's, etc.)

Retrospective dose calculations require actual river flow rates that occurred during the period of release. These can be measured flow rates for the period, or adjustedmeasured flow rates in which actual flow rates are adjusted to reflect measured dilution of tritium in the river. Adjusted flow rates are used in calculations for the annual environmental reports so that calculated doses accurately reflect measured concentration data in the river. Prospective dose calculations use flow rates based on historical average and minimum annual flow, adjusted for dilution of water between the river gauging station and the point of interest.

In the past, the source of information on flow rates was the U.S Geological Survey (USGS) gauging station at the SRS boat dock (one-half mile downstream from the mouth of Upper Three Runs, on the South Carolina side of the river). This gauging station is not calibrated at flow rates exceeding 22,000 cfs because the river protile (cross-section) is not defined at the higher flow rates. Historical data recorded by the Environmental Monitoring Section (EMS) was obtained from gauge readings by the SRS Power Department, using extrapolation of the flow curve above 22,000 cfs when needed. This usually underestimates high flow rates based on comparison with more accurate USGS flow rates at Augusta, GA (New Savannah Lock and Dam). Between 1954 and 1988 (35 years), annual flow rates at the SRS boat dock recorded by the EMS and USGS were lower than at the upstream Augusta gauging station for 19 years (Table 1).

The probable underestimation of flow rates at the SRS boat dock during some years did not cause any offsite doses to be underestimated. However, in the interest of obtaining more accurate flow rate data, flow rates were analyzed at the downstream USGS gauging station at Highway 301. This station is considered accurate at all flow rates by the USGS.

\section{SOURCE OF FLOW RATE DATA}

A summary of annual average Savannah River flow rates was prepared from USGS sources to provide a data set for use in dose calculations for SRS releases.

The USGS measures Savannah River flow at 4 locations below Augusta, GA, i.e., New Savannah Lock and Dam at Bush Field (Augusta), Savannah River near Jackson (SRS Boat Dock), Millhaven, Ga (Highway 301), and at Clyo, GA. The SRS Boat Dock gauging station is not calibrated for flows greater than 22,000 cfs and daily flow rates are not reported by the USGS when the flow exceeds $22,000 \mathrm{cfs}$.

The USGS flow data for all gauging stations are recorded in both paper and digital formats. The USGS office located in each state issues an annual "Water Resources Data Report" for that state and data are also stored in a digital format at USGS headquarters in Reston, VA (Daily Values File). The annual flow data for this summary were obtained from the USGS daily values file for the years from 1950 to 1986 and flows for 1987 and 1988 were obtained from USGS state reports.

Annual flow data were available for the period 1950 through 1988 at Augusta and Clyo. USGS did not start recording flow data for the SRS boat dock until 1972. Prior to 1972, data from the EMS records were used. Between 1972 and 1988, USGS boat dock data were incomplete for 12 of the years because flow rates exceeded 22,000 cfs during parts of these years. Highway 301 flows were not measured in the 1971-1981 time period. A comparison of the flows at Augusta and Highway 301 in the years when data were available (Figure 1) show that the average flows during the missing years at Highway 301 
could be estimated from the flows at Augusta (shown in Figure 2). A correlation coefficient of 0.98 was obtained when the data(Figure 1) were fitted to a simple linear equation, $y=m x+b$; where $y$ is estimated flow at Highway $301, x$ is the measured flow at Augusta, and $m \& b$ are coefficients obtai..ed from the regression analysis. The values for the regression coefficients and their standard errors are: $m=1.1486+-0.0330$ and $b$ $=-202+-298$. These coefficients and the Augusta flows were used to estimate the flow at Highway 301 for the 1971-1981 time period.

A summary of the flow rate data for 1950 - 1988 for the four gauging stations is shown in Table 1. A more detailed summary for each station is given by month and year in Appendix A. Detailed daily records are available from the Environmental Technology Section of SRL on compact disk and magnetic computer media. Table 1 includes a summary of maximum, average, and minimum annual flow rates and minimum and maximum monthly flow rates for the time period 1954 - 1988, the years of SRS operation. The Thurmond Lake Dam was in operation during this entire period.

\section{SELECTED FLOW RATES FOR DOSE CALCULATIONS}

During the period of SRS operation, the average annual flow rate for the period 1954 1988 was 10,500 cfs and the minimum annual average flow rate, which occurred in 1988, was 5,300 cfs at Highway 301 (Table 1 averages were rounded downward). These values will be used for prospective dose calculations for the maximum individual for annual releases. Previous values used were $10,400 \mathrm{cfs}$ for average annual flow and $6,000 \mathrm{cfs}$ for minimum annual flow. The minimum daily flow rate of $3960 \mathrm{cfs}$ occurred on October 25 , 1986. A value of $3,900 \mathrm{cfs}$ will be used for prospective dose calculations for the maximum individual for short term releases, i.e., releases of one day or less.

River flow rates are not measured at the points where the water treatment plants pump water from the river. Beaufort-Jasper water is pumped from River Mile 39 into an eighteen-mile-long canal to the treatment plant. The Beaufort-Jasper treatment plant started operation in 1965. Port Wentworth water is pumped from Abercorn Creek at River Mîle 29 and is piped about seven miles to the treatment plant. This plant was in operation before the startup of SRS operations. In order to develop flow rates for retrospective or prospective calculations of dose to customers of the two downstream water treatment plants, a relationship was developed for adjusting Highway 301 flow rates for additional dilution of non-river water to the river below Highway 301 and additional dilution in the pumping and transport system between the river and the water treatment plants. The method described in Hayes 1983, which is based on tritium concentrations at Highway 301 and at the water treatment plants, was used to develop percent dilution. It was necessary to update these data through 1990 to account for modifications to the water pumping and transport system put into effect at the BeaufortJasper water treatment plant in 1985 . Table 2 shows the data for percent dilution for 1966 - 1990.

From these data, a 121 percent average dilution was calculated for Beaufort-Jasper for 1966 - 1984 and 40 percent dilution for succeeding years. An average dilution of 26 percent was calculated for all years for the Port Wentworth plant. The higher dilution for the Beaufort-Jasper plant can be accounted for by additional dilution in the 18-mile canal system from rainfall (estimated at 4 percent) and ground and surface water. During the period 1965 - 1984, surface water was a large contributor to the dilution in the Beaufort-Jasper canal system. After 1984, surface water dilution was reduced by modifications to this system.

Table 3 shows the Highway 301 flow rate data for the period 1954 - 1988. Also shown are 
derived flow rates to be used in retrospective dose calculation for Beaufort-Jasper and Port Wentworth, based on percent dilution of water downstream of Highway 301. It is emphasized that the derived flow rate data for Beaufort-Jasper and Port Wentworth are not true river flow rates but are numbers to be used in LADTAP computer code input to account for inflow to the river below Highway 301 and additional dilution in the pumping and transport system of the treatment plants. A summary of measured average and minimum flow rates at Highway 301 and derived values for the water treatment plants for prospective dose calculations is shown in Table 4.

\section{REFERENCE}

Hayes, D.W. 1983. "Examples of Savannah River Water Dilution Between the Savannah River Plant and the Beaufort-Jasper and Port Wentworth Water Treatment Plants", DPST-82-1076, January 12, 1983. 
APPENDIX D

Comparison of Aquatic Foods Ingestion Dose Estimates by LADTAP XL and LADTAP II 
Table D-1. Population Dose via Aquatic Foods Ingestion (person-rem).

\begin{tabular}{|c|c|c|c|c|}
\hline \multirow[b]{2}{*}{ Nuclide* } & \multicolumn{2}{|c|}{ Commerical Fish } & \multicolumn{2}{|c|}{ Saltwater Invertebrates } \\
\hline & LADTAP II & LADTAP XL & LADTAP II & LADTAPXL \\
\hline $\mathrm{H}-3$ & $1.8 \times 10^{-9}$ & $1.6 \times 10^{-8}$ & $8.5 \times 10^{-10}$ & $6.4 \times 10^{-7}$ \\
\hline P-32 & $1.3 \times 10^{-2}$ & $1.2 \times 10^{-1}$ & $1.8 \times 10^{-3}$ & $1.3 \times 10^{0}$ \\
\hline S-35 & $1.4 \times 10^{-5}$ & $1.3 \times 10^{-4}$ & $3.8 \times 10^{-9}$ & $2.8 \times 10^{-6}$ \\
\hline Cr-51 & $6.1 \times 10^{-7}$ & $5.4 \times 10^{-6}$ & $2.7 \times 10^{-6}$ & $2.1 \times 10^{-3}$ \\
\hline $\mathrm{Mn}-54$ & $3.4 \times 10^{-5}$ & $3.0 \times 10^{-4}$ & $1.5 \times 10^{-5}$ & $1.2 \times 10^{-2}$ \\
\hline Co-58 & $5.0 \times 10^{-6}$ & $4.5 \times 10^{-5}$ & $4.5 \times 10^{-5}$ & $3.4 \times 10^{-2}$ \\
\hline Co- 60 & $4.2 \times 10^{-5}$ & $3.8 \times 10^{-4}$ & $3.8 \times 10^{-4}$ & $2.8 \times 10^{-1}$ \\
\hline $\mathrm{Zn}-65$ & $8.7 \times 10^{-4}$ & $7.8 \times 10^{-3}$ & $9.8 \times 10^{-3}$ & $7.4 \times 10^{0}$ \\
\hline Sr-89 & $7.0 \times 10^{-6}$ & $6.3 \times 10^{-5}$ & $2.1 \times 10^{-6}$ & $1.6 \times 10^{-3}$ \\
\hline Sr-90 & $1.3 \times 10^{-4}$ & $1.1 \times 10^{-3}$ & $3.8 \times 10^{-5}$ & $2.8 \times 10^{-2}$ \\
\hline Y-91 & $6.2 \times 10^{-6}$ & $5.5 \times 10^{-5}$ & $1.1 \times 10^{-4}$ & $8.4 \times 10^{-2}$ \\
\hline Zr-95 & $3.2 \times 10^{-7}$ & $2.8 \times 10^{-6}$ & $3.5 \times 10^{-6}$ & $2.6 \times 10^{-3}$ \\
\hline $\mathrm{Nb}-95$ & $1.7 \times 10^{-3}$ & $1.5 \times 10^{-2}$ & $2.5 \times 10^{-6}$ & $1.9 \times 10^{-3}$ \\
\hline Mo-99 & $3.5 \times 10^{-8}$ & $4.8 \times 10^{-7}$ & $1.6 \times 10^{-8}$ & $1.8 \times 10^{-5}$ \\
\hline Ru-103 & $7.0 \times 10^{-7}$ & $6.2 \times 10^{-6}$ & $3.1 \times 10^{-5}$ & $2.4 \times 10^{-2}$ \\
\hline Ru-106 & $6.6 \times 10^{-6}$ & $5.9 \times 10^{-5}$ & $3.0 \times 10^{-4}$ & $2.2 \times 10^{-1}$ \\
\hline Sb-124 & $2.6 \times 10^{-7}$ & $2.3 \times 10^{-6}$ & $5.8 \times 10^{-7}$ & $4.4 \times 10^{-4}$ \\
\hline $\mathrm{Sb}-125$ & $8.3 \times 10^{-8}$ & $7.5 \times 10^{-7}$ & $1.9 \times 10^{-7}$ & $1.4 \times 10^{-4}$ \\
\hline I-129 & $1.4 \times 10^{-4}$ & $1.2 \times 10^{-3}$ & $2.0 \times 10^{-4}$ & $1.5 \times 10^{-1}$ \\
\hline I-131 & $8.4 \times 10^{-6}$ & $7.5 \times 10^{-5}$ & $1.3 \times 10^{-5}$ & $9.5 \times 10^{-3}$ \\
\hline Cs-134 & $7.1 \times 10^{-3}$ & $6.4 \times 10^{-2}$ & $2.8 \times 10^{-5}$ & $2.0 \times 10^{-2}$ \\
\hline Cs-137 & $4.8 \times 10^{-3}$ & $4.3 \times 10^{-2}$ & $1.8 \times 10^{-5}$ & $1.4 \times 10^{-2}$ \\
\hline Ba-140 & $5.4 \times 10^{-7}$ & $4.8 \times 10^{-6}$ & $6.1 \times 10^{-6}$ & $4.6 \times 10^{-3}$ \\
\hline La- 140 & $2.9 \times 10^{-8}$ & $2.6 \times 10^{-7}$ & $5.2 \times 10^{-7}$ & $3.9 \times 10^{-4}$ \\
\hline Ce-141 & $6.4 \times 10^{-8}$ & $5.7 \times 10^{-7}$ & $1.7 \times 10^{-5}$ & $1.3 \times 10^{-2}$ \\
\hline Ce-144 & $6.3 \times 10^{-7}$ & $5.6 \times 10^{-6}$ & $1.7 \times 10^{-4}$ & $1.3 \times 10^{-1}$ \\
\hline Pm-147 & $7.6 \times 10^{-7}$ & $6.8 \times 10^{-6}$ & $1.4 \times 10^{-5}$ & $1.0 \times 10^{-2}$ \\
\hline Th-232 & $2.7 \times 10^{-3}$ & $2.4 \times 10^{-2}$ & $8.2 \times 10^{-2}$ & $6.1 \times 10^{1}$ \\
\hline U-234 & $1.7 \times 10^{-5}$ & $1.5 \times 10^{-4}$ & $3.8 \times 10^{-5}$ & $2.9 \times 10^{-2}$ \\
\hline U-235 & $1.6 \times 10^{-5}$ & $1.4 \times 10^{-4}$ & $3.7 \times 10^{-5}$ & $2.7 \times 10^{-2}$ \\
\hline U-237 & $4.6 \times 10^{-8}$ & $4.1 \times 10^{-7}$ & $1.0 \times 10^{-7}$ & $7.8 \times 10^{-5}$ \\
\hline U-238 & $1.5 \times 10^{-5}$ & $1.3 \times 10^{-4}$ & $3.4 \times 10^{-5}$ & $2.5 \times 10^{-2}$ \\
\hline Np-239 & $2.1 \times 10^{-8}$ & $1.8 \times 10^{-7}$ & $9.3 \times 10^{-9}$ & $6.9 \times 10^{-6}$ \\
\hline $\mathrm{Pu}-238$ & $4.3 \times 10^{-4}$ & $3.9 \times 10^{-3}$ & $1.1 \times 10^{-2}$ & $8.3 \times 10^{0}$ \\
\hline Pu-239 & $4.9 \times 10^{-4}$ & $4.4 \times 10^{-3}$ & $1.3 \times 10^{-2}$ & $9.4 \times 10^{0}$ \\
\hline Am-241 & $3.6 \times 10^{-3}$ & $3.3 \times 10^{-2}$ & $6.6 \times 10^{-2}$ & $4.9 \times 10^{1}$ \\
\hline $\mathrm{Cm}-244$ & $1.9 \times 10^{-3}$ & $1.7 \times 10^{-2}$ & $3.4 \times 10^{-2}$ & $2.5 \times 10^{1}$ \\
\hline Total & $3.7 \times 10^{-2}$ & $3.3 \times 10.1$ & $2.2 \times 10.1$ & $1.6 \times 10^{2}$ \\
\hline
\end{tabular}

* source term is a one curie release of each of the nuclides listed. 
Table D-2. Maximum Individual Dose via Shoreline Exposure (mrem).

\begin{tabular}{|c|c|c|}
\hline Nuclide* & $\begin{array}{l}15 \text { Year Buildup } \\
\text { LADTAP II }\end{array}$ & $\begin{array}{l}40 \text { Year Buildup } \\
\text { LADTAP XI }\end{array}$ \\
\hline H-3 & $0.0 \times 100$ & $0.0 \times 10^{0}$ \\
\hline P-32 & $0.0 \times 10^{0}$ & $0.0 \times 10^{0}$ \\
\hline S-35 & $0.0 \times 10^{0}$ & $0.0 \times 10^{0}$ \\
\hline Cr-51 & $5.2 \times 10^{-7}$ & $5.2 \times 10^{-7}$ \\
\hline$M n-54$ & $1.5 \times 10^{-4}$ & $1.5 \times 10^{-4}$ \\
\hline Co-58 & $3.9 \times 10^{-5}$ & $3.9 \times 10^{-5}$ \\
\hline $\mathrm{Co}-60$ & $2.1 \times 10^{-3}$ & $2.5 \times 10^{-3}$ \\
\hline $\mathrm{Zn}-65$ & $7.5 \times 10^{-5}$ & $7.5 \times 10^{-5}$ \\
\hline Sr-89 & $3.8 \times 10^{-9}$ & $3.8 \times 10^{-9}$ \\
\hline Sr-90 & $0.0 \times 10^{0}$ & $0.0 \times 10^{0}$ \\
\hline$Y-91$ & $1.1 \times 10^{-7}$ & $1.1 \times 10^{-7}$ \\
\hline$Z r-95$ & $5.4 \times 10^{-5}$ & $5.4 \times 10^{-5}$ \\
\hline Nb-95 & $1.5 \times 10^{-5}$ & $1.5 \times 10^{-5}$ \\
\hline Mo-99 & $3.5 \times 10^{-7}$ & $3.5 \times 10^{-7}$ \\
\hline Ru-103 & $1.1 \times 10^{-5}$ & $1.1 \times 10^{-5}$ \\
\hline Ru-106 & $4.4 \times 10^{-5}$ & $4.4 \times 10^{-5}$ \\
\hline Sb-124 & $5.9 \times 10^{-5}$ & $5.9 \times 10^{-5}$ \\
\hline Sb-125 & $2.4 \times 10^{-4}$ & $2.5 \times 10^{-4}$ \\
\hline$I-129$ & $4.7 \times 10^{-5}$ & $1.3 \times 10^{-4}$ \\
\hline I-13I & $1.7 \times 10^{-6}$ & $1.7 \times 10^{-6}$ \\
\hline Cs-134 & $6.7 \times 10^{-4}$ & $6.7 \times 10^{-4}$ \\
\hline Cs-137 & $1.0 \times 10^{-3}$ & $2.2 \times 10^{-3}$ \\
\hline $\mathrm{Ba}-140$ & $1.6 \times 10^{-5}$ & $1.6 \times 10^{-5}$ \\
\hline La-140 & $1.3 \times 10^{-6}$ & $1.3 \times 10^{-6}$ \\
\hline Ce-141 & $1.6 \times 10^{-6}$ & $1.6 \times 10^{-6}$ \\
\hline Ce-144 & $8.1 \times 10^{-6}$ & $8.1 \times 10^{-6}$ \\
\hline Pm-147 & $2.2 \times 10^{-9}$ & $2.2 \times 10^{-9}$ \\
\hline Th-232 & $1.4 \times 10^{-6}$ & $3.8 \times 10^{-6}$ \\
\hline U-234 & $1.7 \times 10^{-6}$ & $4.6 \times 10^{-6}$ \\
\hline U-235 & $3.7 \times 10^{-4}$ & $9.8 \times 10^{-4}$ \\
\hline U-237 & $5.5 \times 10^{-7}$ & $5.5 \times 10^{-7}$ \\
\hline U-238 & $1.4 \times 10^{-6}$ & $3.7 \times 10^{-6}$ \\
\hline$N_{p-239}$ & $1.9 \times 10^{-7}$ & $1.9 \times 10^{-7}$ \\
\hline $\mathrm{Pu}-238$ & $1.7 \times 10^{-6}$ & $4.2 \times 10^{-6}$ \\
\hline Pu-239 & $8.1 \times 10^{-7}$ & $2.2 \times 10^{-6}$ \\
\hline Am-241 & $6.3 \times 10^{-5}$ & $1.7 \times 10^{-4}$ \\
\hline $\mathrm{Cm}-244$ & $1.3 \times 10^{-6}$ & $2.4 \times 10^{-6}$ \\
\hline Total & $5.0 \times 10^{-3}$ & $7.3 \times 10^{-3}$ \\
\hline
\end{tabular}

* source term is a one curie release of each of the nuclides listed. 

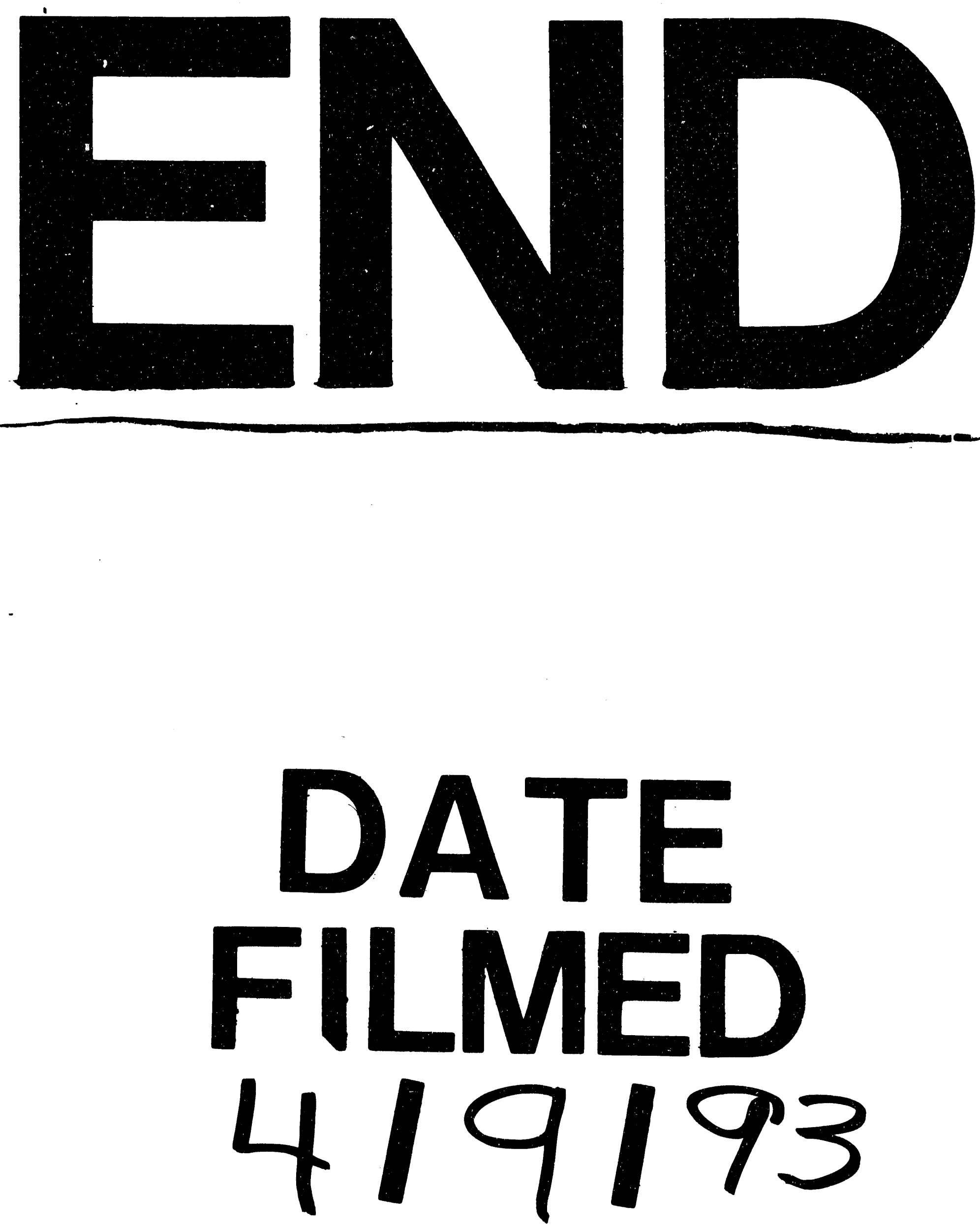


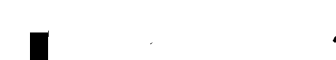

